\title{
CRIMES TRIBUTÁRIOS SOB A ÓTICA DA CRIMINOLOGIA CRÍTICA: EXTINÇÃO DE PUNIBILIDADE PELO PAGAMENTO DO TRIBUTO E A TEORIA DO ETIQUETAMENTO
}

Mary Cristina Neves Mansoldo ${ }^{1}$

\begin{abstract}
Resumo
O estudo apresentado tem o escopo de analisar os crimes tributários sob a ótica da Criminologia crítica, no que diz respeito à extinção de punibilidade pelo pagamento do tributo devido e pela análise do labeling approach ou teoria do etiquetamento, que questiona os mecanismos de seleção criminal do atual sistema punitivo, analisandose a diferenciação de tratamentos entre os delitos comuns e fiscais. $\mathrm{O}$ arcabouço teórico sobre assuntos criminológicos e tributários e a jurisprudência predominante foram relevantes para o desenvolvimento do estudo em seus métodos de pesquisa doutrinária e jurisprudencial. Concluiu-se que a seleção do sistema penal viola as finalidades da Ordem Econômica, dispostas no art. 170 da Constituição Federal de 1988, bem como, os Direitos Fundamentais, individuais e coletivos, consagrados pela Carta Maior em seu art. $5^{\circ}$. Observou-se que para a criação de políticas criminais que atendam as atuais necessidades sociais é fundamental a união da ciência do Direito Penal com a ciência da Criminologia, em uma ótica crítica, para que os objetivos sociais sejam alcançados. Em suma, a pesquisa explorou um tema que merece muita atenção do Estado e da sociedade, ou seja, o processo de criminalização do sistema penal brasileiro.
\end{abstract}

Palavras-chave: Criminologia crítica; Direito Penal Tributário; Delitos fiscais; Extinção punitiva pelo pagamento; Teoria do etiquetamento.

\section{INTRODUÇÃO}

A criminologia crítica pode, e deve, interferir valorativamente na política criminal. A ideia é exatamente esta: a busca de uma política criminal para os excluídos, para aqueles que são clientela preferencial dos processos perversos de seleção de criminalização. (BARATTA, Alessandro, 1999, p. 200).

A ciência do Direito Penal se desenvolve em constante adequação social, o que significa que tanto a conduta individual como as relações sociais influenciam de maneira relevante na estruturação legal do Direito Penal.

No âmbito do Direito Penal, encontra-se o Direito Penal Tributário que tipifica crimes com fatos tributários. A Lei no 8.137, de 1990, dispõe sobre os crimes contra a Ordem Tributária.

\footnotetext{
${ }^{1}$ Doutoranda em Criminologia pela Universidade do Porto. Professora Universitária no Curso de Direito nas disciplinas de Direito Penal, Processo Penal, Criminologia e Metodologia da Pesquisa Científica.E-mail: consultoria@docenciaedireito.com
} 
No que diz respeito à extinção da punibilidade pelo pagamento integral do tributo devido, apesar de tantas alterações legislativas, é vigente, ainda, a disposição do $\$ 2^{\circ}$, do art. $9^{\circ}$, da Lei nº 10.684 , de 2003, que dispõe que com o pagamento integral, a qualquer tempo, extingue-se a punibilidade estatal, afastando-se do sujeito ativo do delito fiscal, a persecução penal, a execução criminal e a possibilidade de que o agente chegue ao estabelecimento prisional.

Nesse contexto, relevante a comparação com o delito comum, por exemplo, o delito do furto disposto no art. 155 do Código Penal Brasileiro (Decreto-lei no. 2.848, de 7 de dezembro de 1940). Nesse caso, ocorrendo devolução da res furtiva à vítima, isto de maneira espontânea e voluntária, não haverá à extinção de punibilidade, apenas, a diminuição de pena, prevista no art. 16 do $\mathrm{CP}$, pelo instituto do arrependimento posterior ou, dependendo do momento de restituição, pela atenuante genérica do art. 65, inciso III, alínea "b" do CP.

Nos dois casos exemplificados, estará havendo a restituição do objeto material do delito, ou seja, no caso do delito fiscal, a restituição do valor correspondente ao tributo devido e no caso do furto, a restituição do valor furtado. Não teriam os dois delitos condutas ilicitas semelhantes?

Pela análise comparativa, indaga-se sobre a diferenciação nas consequências geradas pelos pagamentos ou restituições, isto é, a extinção de punibilidade e a diminuição de pena, podendo-se chegar a outra indagação: como entender tal seleção penal?

Uma das possíveis respostas foi defendida pela Criminologia crítica, mais especificamente, pela teoria do etiquetamento social.

É salutar a observação de que outras teorias da Criminologia contemporânea já avançaram sobre as questões em análise, contrapondo-se ou complementando as teses defendidas pela teoria do etiquetamento.

Na teoria do labeling approach (teoria do etiquetamento) o enfoque da Criminologia muda e a pergunta passa a ser: por que algumas pessoas são rotuladas pela sociedade e outras não?

Assim, o questionamento da presente pesquisa é: a partir da teoria do etiquetamento, como pensar os crimes tributários e a possibilidade de extinção de punibilidade pelo pagamento do tributo devido?

Para o desenvolvimento da pesquisa foram necessários estudos direcionados aos Crimes contra a Ordem Tributária, expostos no Capítulo I, a ciência da Criminologia, iniciando-se por sua evolução histórica até a conceituação e as características da Criminologia crítica, especificando-se a teoria do etiquetamento, expostos no Capítulo II e a construção de uma perspectiva criminológica crítica em relação aos crimes tributários, exposta no Capítulo III, para, por fim, serem dispostas as conclusões e considerações finais.

A pesquisa científica se justifica pela necessária compreensão da diferenciação entre delitos comuns e fiscais, pois, o que se tem são controvérsias sobre a questão problemática. 
Como, também, justifica-se a pesquisa, pelo momento atual da sociedade brasileira, no qual é perceptível um desequilíbrio considerável entre as receitas e as despesas estatais.

Foram utilizados como métodos às pesquisas bibliográfica e jurisprudencial, caracterizados pelo estudo teórico em profundidade dos temas. Objetivou-se fundamentar respostas que atendam à problemática inicialmente formulada, por meio de uma construção progressiva de estudos e pesquisas, contribuindo de forma significativa no desenvolvimento do Direito Penal Tributário, porém, com uma visão criminológica crítica.

\section{CRIMES CONTRA A ORDEM TRIBUTÁRIA}

O atual fenômeno da mundialização influencia no desenvolvimento do país em vários aspectos, porém, com a amplitude de novos conhecimentos, há, também, o aumento do risco social, principalmente, no âmbito do índice de criminalidade. Neste contexto, o Direito Penal se encontra fragilizado, por ter o suposto dever de conter a criminalidade e, até mesmo, extingui-la.

Em aspecto geral, o fenômeno da mundialização trouxe uma profunda mudança social que impactou as perspectivas da ciência do Direito Penal.

Vários conflitos sociais diferenciados se desenvolveram e salientaram a necessidade de proteção de bens supraindividuais, que até então eram desapercebidos, um bom exemplo pode ser verificado na ocorrência do crime tributário. (SHIRAKI, 2010).

Pela atual realidade social, pelo dinamismo econômico, pelos avanços tecnológicos, pelo aumento de produções, pelo desenvolvimento da atuação e influência dos meios de comunicação, o Direito Penal tradicional se torna ultrapassado, pois, novas condutas ilícitas se tornaram habituais nas relações sociais ou no desenvolvimento da sociedade.

Crimes diferenciados como os que envolvem o meio ambiente, o sistema financeiro, a ordem econômica, a previdência pública e a livre concorrência, começam a surgir ou suas técnicas criminológicas são aperfeiçoadas, ocasionando o estremecimento das bases do Direito Penal tradicional e ortodoxo. (OLIVEIRA E SILVA, 2006).

Percebe-se que as infrações penais tipificadas pelo Direto Penal, incluindo as legislações penais extravagantes, tendem a expansão, ou seja, novas condutas ilícitas surgem a todo o momento. (DIAS, 2006).

$\mathrm{Na}$ atualidade, o delinquente que não se adapta à sociedade, inclusive, pela influência da má distribuição de renda que vigora no País, não pode mais ser o único alvo da delinquência e sua penalização. Conforme Artur Pinto de Lemos Júnior, as técnicas criminosas foram aperfeiçoadas e a criminalidade ampliou suas fronteiras. E, ainda, há o desenvolvimento da criminalidade coletiva inserida nos âmbitos econômico, político e social. (LEMOS JÚNIOR, 2006). 
O que se percebe é que os moldes iluministas do direito de liberdade, direito do ser humano e direitos individuais, são superados na atualidade por uma realidade maior e mais problemática, as violações aos direitos coletivos.

Em suma, tem-se o aumento da criminalidade coletiva, como, também, o aumento de violações aos direitos coletivos.

$\mathrm{Na}$ tutela dos direitos coletivos, encontra-se a tutela penal da Ordem Tributária que no Brasil se instrumentaliza pela Lei no. 8.137/90.

Importante salientar que tanto os direitos individuais como os coletivos são direitos fundamentais do Estado Democrático de Direito. Por outras palavras, conforme Gregório Assagra de Almeida (2008), os direitos fundamentais, reconhecidos pela Constituição Federal brasileira de 1988, passaram a consagrar uma nova summa divisio constitucionalizada, ou seja, o direito individual e o direito coletivo. A tutela constitucional deixou de ser restringida e diferenciada pelos critérios privativo e público, passando a abranger os verdadeiros e atuais âmbitos conflituosos (ou não) da sociedade.

Em relação ao reconhecimento dos direitos coletivos como direitos fundamentais, observa-se uma dimensão de consciência democrática nunca antes reconhecida na história evolutiva da Nação. Os direitos fundamentais deixaram seus limites individuais, passando, também, a proteger a coletividade, o grupo, a sociedade que possui direitos difusos, cujos efeitos atingem números indeterminados de afetados, de violados e, portanto, legitimados. (ALMEIDA, 2008).

Concluindo a análise introdutória, é perceptível que o Direito Penal não poderá atuar sozinho em busca de soluções para as problemáticas da atualidade, certamente, dependerá das ciências erroneamente conhecidas como auxiliares, como a ciência da Criminologia, para que a política criminal seja adequada às novas realidades sociais.

\section{Direito Penal}

Conforme o Ordenamento Jurídico brasileiro crime é toda a ação ou omissão, típica, antijurídica e culpável. Ação se refere a uma conduta positiva (comissiva) e omissão se refere a uma conduta negativa (omissiva).

Há os crimes comissivos por omissão, por exemplo: mãe que, desejando matar o filho, não o alimenta. No exemplo, a ação é consumada pelo desejo de matar e a omissão se caracteriza pela forma de matar.

Para ser ação ou omissão típica, deve haver na lei um tipo penal que corresponda com a conduta do agente (tipicidade - princípio da reserva legal).

A conduta não será antijurídica quando houver uma excludente de ilicitude, ou seja, quando houver 
justificativa legal (arts. 23 a 25 do CP).

Como, também, não haverá culpabilidade quando não houver dolo nem culpa na conduta do agente, por exemplo, quando o agente age sendo coagido, tratando-se, portanto, de uma excludente de culpabilidade.

Para a efetivação das regras e conceitos do crime no âmbito tributário, o Direito Penal, conforme Professor Alexandre Sanches Cunha² , encontra-se em dificuldades nos seguintes aspectos:

1. ausência de uma regulação jurídica unitária e sistemática deste setor de "delinqüência econômica".

2. com a extensão desmesurada do conceito de delito econômico, corre-se o risco de perder qualquer possibilidade de delimitar esse novo ramo do Direito Penal e identificar o bem jurídico comum a todas e cada uma das diversas infrações coletivas.

3. o fato de que societas delinquere non potest.

O professor Alexandre ainda salienta que:

Vale lembrar que apenas o ser humano é DOLI CAPAX, não se afastando, nestes casos, a idéia central que já vimos sobre a culpabilidade. Não há como punir a pessoa jurídica e os crimes praticados em nome da sociedade. Somente podemos punir seus mandatários desde que comprovada a sua participação nos fatos.

\section{Direito Penal Econômico}

A Ordem Econômica, em sentido amplo, é o conjunto de normas que, além de institucionalizar, regula as relações econômicas em um determinado ordenamento, englobando o sistema financeiro, o sistema cambial, o sistema de proteção aos consumidores e a Ordem Tributária.

Conforme a Constituição Federal, a Ordem Econômica é um bem jurídico composto pela política urbana, a política agrícola, a política fundiária e o sistema financeiro nacional.

O Direito Econômico e o Direito Penal Econômico possuem o mesmo objeto de tutela, ou seja, a Ordem Econômica.

Por uma breve análise histórica, para Adam Smith, os movimentos que constroem o mercado ocorrem de forma espontânea e, tanto a indústria como o comércio devem ser livres para atuarem, o que significa que não deve haver influência ou interferência estatal. (SMITH, 1983).

Certamente, a referida conceituação de Adam Smith foi severamente criticada, principalmente, a partir do Século XIX, pelas correntes denominadas socialistas. Assim, o Estado Liberal se desestabilizou e as concepções marxistas se fizeram notar. (COSTA, 2006).

Por outro lado, o Estado precisava sair de sua inércia e passar a proteger os hipossuficientes, aqueles

\footnotetext{
${ }^{2}$ Graduado em Ciências Jurídicas pela PUC-Campinas, Bacharel em Filosofia pela UNICAMP, Especialista em Direito Penal pela PUC-Campinas e Mestre em Filosofia Clássica pela UNICAMP. Material de apoio disponibilizado pelo professor no curso de pós-graduação em Direito Tributário da Universidade Paulista (UNIP).
} 
desprovidos de poder social e financeiro, promovendo a igualdade social e a solução era intervir na livre iniciativa do mercado. Assim, surge o Direito Econômico moderno como ciência autônoma. (COSTA, 2006).

Pelas palavras de José Afonso da Silva:

A atuação do Estado, assim, não é nada menos do que uma tentativa de pôr ordem na vida econômica e social, de arrumar a desordem que provinha do liberalismo. Isso tem efeitos especiais, porque importa em impor condicionamentos à atividade econômica, do que derivam os direitos econômicos que consubstanciam o conteúdo da constituição econômica. (SILVA, 2000. p.764).

O Direito Penal Econômico, no entanto, tem o sistema penal como proteção dos bens tutelados, criando condutas ilícitas e suas respectivas penalizações.

Pelos ensinamentos de Manoel Pedro Pimentel, o Direito Penal Econômico é: "o conjunto de normas que tem por objeto sancionar, com as penas que lhe são próprias, as condutas que, no âmbito das relações econômicas, ofendam ou ponham em perigo bens ou interesses juridicamente relevantes". (PIMENTEL, 1973. p.10). E, ainda, o autor elucida que:

O Direito penal econômico, portanto, é um sistema de normas que defende a política econômica do Estado, permitindo que esta encontre os meios para a sua realização. São, portanto, a segurança e a regularidade da realização dessa política que constituem precipuamente o objeto jurídico do Direito penal econômico. (PIMENTEL, 1973, p. 21).

Os crimes econômicos estão ligados às questões sociológicas e políticas. Por exemplo: sonegação fiscal (camadas sociais mais privilegiadas).

Nestes crimes há mais tolerância da sociedade e impunidade. E, conforme Pimentel, é criado o chamado "contágio hierárquico". Isto é, exemplos negativos são dados pela classe mais privilegiada à classe menos privilegiada. Para Pimentel, é necessária a mudança de atitudes sociais, pois, apenas, o esforço para maior eficiência da ação policial não é suficiente, salientando o autor que os comportamentos desviantes, aceitáveis nas altas camadas sociais (como moral dos negócios), geram condutas nas parcelas mais humildes. Ou seja, a impunidade das elites contagia todas as classes sociais, porém, somente nas mais humildes é que as referidas condutas são consideradas e institucionalizadas como crimes ou contravenções penais. (PIMENTEL, 1983).

Mas, por fim, pode-se concluir que o Direito Econômico cuida da ordem econômica e dos crimes econômicos. Direito Público Econômico disciplina a intervenção do Estado na ordem econômica e o Direito Tributário é uma expressão do Direito Econômico.

\section{O Direito Penal Tributário}

Inicialmente, são salutares alguns apontamentos sobre conceituações da Ordem Tributária, bem jurídico fundamental e protegido pelo Direito Penal, além de ser objeto material dos crimes tributários. Conforme Hugo de Britto Machado: 
Ordem Tributária pode ser entendida como o complexo de normas jurídicas limitadoras do poder de instituir e cobrar tributos, vale dizer, o complexo de normas jurídicas limitadoras do exercício do poder de tributar ( ... . . Assim, os crimes contra a Ordem Tributária são crimes praticados em detrimento da eficácia dessas normas. (MACHADO, 2011, p. 328-329).

Pelo autor, portanto, de maneira mais específica, será justamente a eficácia das normas que protegem a Ordem Tributária que será violada nos delitos fiscais.

Há teorias que explicam a aplicabilidade e conceituações dos delitos contra a Ordem Tributária, ou seja, a aplicabilidade do Direito Penal Tributário.

Pela teoria administrativa, as infrações fiscais, por atingirem bens coletivos do Estado, não se assemelham com as infrações penais comuns. Entende-se que as infrações fiscais são condutas ilícitas que afetam a ordem econômica ou tributária e as infrações comuns afetam a moral. Assim, pela teoria administrativa, as penalidades das infrações fiscais devem ser pecuniárias e não privativas de liberdade.

Pela teoria tributarista, o Direito Penal Tributário é um ramo do Direito Tributário, portanto, a penalização destas espécies delituosas possui origem no próprio poder tributário do Estado. Por causa desta definição, Susana Aires de Souza entende que o correto seria a expressão de Direito Tributário Penal e não ao contrário, pois, as raízes são tributárias e não penais. (SOUZA, 2006).

Pela teoria penalista, o entendimento é oposto, o Direito Penal Tributário se refere ao Direito Penal especial. Isto é, há legislação penal especial em que são tipificadas condutas ilícitas onde se tem um fato criminoso tributário e que ofendem a Ordem Tributária, porém, como toda a legislação penal extravagante, há submissão da lei penal especial aos princípios e garantias previstos no Código Penal e no Código Processual Penal. Sendo, por fim, o Direito Penal Tributário um ramo do Direito Penal.

O Brasil adotou a teoria penalista, o que significa que os delitos fiscais se submetem as normas e os princípios do Direito Penal e processual penal. O que, também, leva-se a conclusão, excluindo as peculiaridades, que o delito tributário não se diferencia do delito penal comum. Conforme explica Emerson Lima Pinto, o Direito Penal Tributário é:

O conjunto de normas que regulam os delitos tributários e as respectivas sanções”, sendo certo que o adjetivo "tributário" pretende apenas dizer que as normas penais, que fazem parte da disciplina matriz, colocam sob sua tutela matéria tributária. (LIMA PINTO, 2001, p. 2634).

Os crimes contra a Ordem Tributária são descumprimentos de obrigações tributárias e ensejam um desencadeamento de atos administrativos (procedimentos):

1. tomados de ofício;

2. averiguação da falta;

3. medição dos efeitos;

4. exigência do tributo; 
5. apenamento previsto.

O procedimento administrativo tributário é contencioso e visa o controle de legalidade do ato administrativo do lançamento.

No Brasil, a lei que tipifica e regula os delitos fiscais é a Lei no. 8.137/90, que considera como delitos contra a Ordem Tributária duas situações fáticas precisas e distintas: a primeira é "suprimir tributo ou contribuição ou acessório", mediante as condutas que consigna como "supressão" ou "redução", e a segunda é a previsão, numerus clausus, das condutas que podem levar à sonegação. (CORRÊA, 1994).

Importante ressaltar que as condutas ilícitas tipificadas pela Lei no 4.729/65, crimes de sonegação fiscal, foram absorvidas pela Lei no. 8.137/90, portanto, passaram a ser denominadas como crimes contra a Ordem Tributária.

As condutas ilícitas contra a Ordem Tributária, cometidas por particulares, são dispostas nos arts. $1^{\circ} \mathrm{e} 2^{\circ}$ da Lei no. 8.137/90 e as condutas ilícitas praticadas por funcionário público estão dispostas no art. $3^{\circ}$ da Lei (CAPEZ, 2012).

$\mathrm{O}$ artigo $1^{\circ}$ trata de delitos fiscais cometidos por particular, especificamente sobre a supressão ou redução de tributos. Nesse sentido, Machado esclarece que tais condutas se referem a crimes materiais de dano, ou seja, torna-se necessária a ocorrência finalística do resultado. (MACHADO, 2011). Assim é disposto no art. $1^{\circ}$ da Lei:

Art. $1^{\circ}$ Constitui crime contra a Ordem Tributária suprimir ou reduzir tributo, ou contribuição social e qualquer acessório, mediante as seguintes condutas:

I - omitir informação, ou prestar declaração falsa às autoridades fazendárias;

II - fraudar a fiscalização tributária, inserindo elementos inexatos, ou omitindo operação de qualquer natureza, em documento ou livro exigido pela lei fiscal;

III - falsificar ou alterar nota fiscal, fatura, duplicata, nota de venda, ou qualquer outro documento relativo à operação tributável;

IV - elaborar, distribuir, fornecer, emitir ou utilizar documento que saiba ou deva saber falso ou inexato;

$\mathrm{V}$ - negar ou deixar de fornecer, quando obrigatório, nota fiscal ou documento equivalente, relativa a venda de mercadoria ou prestação de serviço, efetivamente realizada, ou fornecê-la em desacordo com a legislação.

Pena - reclusão de 2 (dois) a 5 (cinco) anos, e multa. (BRASIL, Lei no 8.137 de 1990).

No artigo $2^{\circ}$, em seus incisos, são expostas outras condutas ilícitas cometidas por particulares. Como no inciso I, a conduta do crime de inadimplemento fraudulento de obrigação acessória. Assim é disposto no art. 2 da Lei:

Art. $2^{\circ}$ Constitui crime da mesma natureza:

I - fazer declaração falsa ou omitir declaração sobre rendas, bens ou fatos, ou empregar outra fraude, para eximir-se, total ou parcialmente, de pagamento de tributo;

II - deixar de recolher, no prazo legal, valor de tributo ou de contribuição social, descontado ou cobrado, na qualidade de sujeito passivo de obrigação e que deveria recolher aos cofres públicos;

III - exigir, pagar ou receber, para si ou para o contribuinte beneficiário, qualquer 
percentagem sobre a parcela dedutível ou deduzida de imposto ou de contribuição como incentivo fiscal;

IV - deixar de aplicar, ou aplicar em desacordo com o estatuído, incentivo fiscal ou parcelas de imposto liberadas por órgão ou entidade de desenvolvimento;

$\mathrm{V}$ - utilizar ou divulgar programa de processamento de dados que permita ao sujeito passivo da obrigação tributária possuir informação contábil diversa daquela que é, por lei, fornecida à Fazenda Pública.

Pena - detenção, de 6 (seis) meses a 2 (dois) anos, e multa. (BRASIL, Lei no 8.137 de 1990).

Para Machado as condutas dos tipos penais do art. 20 "dizem respeito a fato relevante do ponto de vista tributário, vale dizer, fato que participa na formação da relação obrigacional tributária." (MACHADO, 2011, p. $391)$.

No art. $2^{\circ}$ o crime é formal, independe do resultado, trata-se, também, de infração de menor potencial ofensivo, estando sujeita às disposições da Lei n. 9.099/95, assim, é cabível a suspensão condicional do processo (art. 89 da Lei dos Juizados Especiais). (CAPEZ, 2012).

No artigo $3^{\circ}$ da Lei são dispostas as condutas ilícitas cometidas por funcionários públicos, ou seja, crimes funcionais. Observa-se que o Código Penal dispõe sobre crimes funcionais, mas, a Lei Penal extravagante dos crimes contra a Ordem Tributária, também, criou tipos de crimes funcionais, assim dispostos:

Art. $3^{\circ}$ Constitui crime funcional contra a Ordem Tributária, além dos previstos no :

I - extraviar livro oficial, processo fiscal ou qualquer documento, de que tenha a guarda em razão da função; sonegá-lo, ou inutilizá-lo, total ou parcialmente, acarretando pagamento indevido ou inexato de tributo ou contribuição social;

II - exigir, solicitar ou receber, para si ou para outrem, direta ou indiretamente, ainda que fora da função ou antes de iniciar seu exercício, mas em razão dela, vantagem indevida; ou aceitar promessa de tal vantagem, para deixar de lançar ou cobrar tributo ou contribuição social, ou cobrá-los parcialmente. Pena - reclusão, de 3 (três) a 8 (oito) anos, e multa.

III - patrocinar, direta ou indiretamente, interesse privado perante a administração fazendária, valendo-se da qualidade de funcionário público. Pena - reclusão, de 1 (um) a 4 (quatro) anos, e multa. (BRASIL, Lei no 8.137 de 1990).

Em suma, nos crimes definidos nos artigos 1. ${ }^{\circ}$ e 2. ${ }^{\circ}$, o sujeito ativo é o contribuinte. Todavia, também, poderão praticar os crimes supracitados, o contador, o advogado, entre outros.

O sujeito ativo do artigo 3. é o funcionário público (crime próprio e funcional típico). O sujeito passivo é o Erário.

Tratando-se de pessoa jurídica, faz-se necessário apurar a participação dos sócios, porém, deverá ser excluído da ação penal, a pessoa que, embora figure no contrato social, não tenha qualquer poder de comando ou que não tenha vínculo com o resultado criminoso. No âmbito do processo penal tributário é salutar observar que em relação à denúncia do Ministério público, não há a possibilidade das chamadas "denúncias genéricas", isto é, as acusações genéricas não são aceitas, pois, o fato deve ser narrado de maneira que possa permitir a ampla defesa e o contraditório (no âmbito processual) e irá fundamentar a culpabilidade (no âmbito penal).

A ação penal é pública incondicionada nos crimes previstos nos artigos 1.․ 2..$^{\circ}$ e 3. . Com o advento da Lei n. 9.430/1996, especificamente no que é pertinente ao seu artigo 83, vedou-se à autoridade fazendária a 
remessa de notícia de crime (a qual o tipo penal denomina "representação") ao Ministério Público, antes do término do procedimento administrativo fazendário. (MACHADO, 2011).

No que diz respeito à competência, tratando-se de tributo da União é competente a Justiça Federal. Se o tributo é estadual ou municipal, a competência será da Justiça Estadual. Observa-se que, compete a Justiça Federal o processo e julgamento unificado dos crimes conexos de competência federal e estadual, conforme Súmula 122 do STJ: "Compete à Justiça Federal o processo e julgamento unificado dos crimes conexos de competência federal e estadual, não se aplicando a regra do art. 78, II, “a”, do Código de Processo Penal”.

Em relação ao instituto de deleção premiada, poderá haver a redução de um terço a dois terços da condenação nas hipóteses de crimes tipificados na Lei n. 8.137/1990, os quais sejam cometidos em co-autoria ou quadrilha, aproveitando referido benefício ao agente que revelar toda à trama delituosa. Não é exigível o desmantelamento da quadrilha, contentando-se a Lei com as informações detalhadas acerca do cometimento da infração, tais como o tempo do crime, seus agentes, o modo de execução, a vantagem obtida com o ilícito etc. Os requisitos do instituto da delação são os seguintes:

a. crimes previstos na Lei;

b. praticado sem concurso ou quadrilha;

c. delação à autoridade policial ou judicial, sendo revelada toda à trama delituosa;

d. delação espontânea.

\section{Extinção da punibilidade pelo pagamento do tributo}

O Brasil possui uma das mais altas cargas tributárias e, por consequência, um número elevado de demandas judiciais que visam à execução de dívidas tributárias, mas, este número de demandas judiciais não se compara com o número de processos criminais visando à punição penal dos agentes delituosos, ou seja, nestes casos o número é bem menor. E, certamente, o que provoca esta diferença de números é o instituto da extinção de punibilidade.

A extinção da punibilidade está disciplinada no art. 107 do Código Penal, que apresenta um rol exemplificativo e não taxativo, pois, há outras formas de extinção de punibilidade previstas na Parte Especial do Código, bem como, em leis penais extravagantes. Como ocorre com a Lei de crimes contra a Ordem Tributária que especifica formas de extinção de punibilidade. (NUCCI, 2009).

O direito de punir (jus puniendi) do Estado surge a partir do momento em que a conduta ilícita foi tentada ou consumada. Alguns doutrinadores identificam que, a partir deste momento, o jus puniendi deixa seu estado abstrato e passa a ser um jus puniendi concreto. Referindo-se ao fato do jus puniendijá existir antes mesmo da violação do bem, explica Válter Kenji Ishida: 
Esse direito existe, não se tratando somente de uma expectativa de direito e fundamenta, por exemplo, a busca pessoal da polícia em razão de fundada suspeita a que alude o art. 240, \$ $2^{\circ}$, do CPP. Se um policial revista uma pessoa na rua, não significa que essa pessoa esteja praticando um crime. Só existe nesse caso o exercício do jus puniendi in abstrato. (ISHIDA, 2010, p. 2).

Para outros doutrinadores, com a ocorrência da tentativa ou da consumação do delito, o Estado passa a ter a pretensão punitiva.

A punibilidade, portanto, é uma reação do Estado por se tratar de uma consequência da conduta ilícita e não faz parte de forma explícita na conduta tipificada. Assim, a punibilidade, sobrevindo causas específicas, pode ser extinta, sendo eliminada a imposição do jus puniendi. (REGIS PRADO, 2004).

As causas extintivas da punibilidade podem ocorrer por eventos naturais, pela vontade do Estado ou pela vontade do próprio ofendido ou agente e, por consequência, impedem a aplicação da sanção penal e podem ocorrer durante ou após a ocorrência do fato criminoso. (SCHMMIDT, 2003).

Como, também, explica Edmar Oliveira Andrade Filho que: "as causas de extinção da punibilidade atuam como inibidoras da aplicação da sanção penal, extinguindo o direito que tem o Estado de aplicar punição quando da ocorrência de crime de qualquer natureza." (ANDRADE FILHO, 1995, p.135).

Serão discricionárias quando dependerem do parecer e entendimento do juiz, como no caso do instituto do perdão judicial e serão obrigatórias quando forem determinadas por lei, como exemplo, a extinção da punibilidade pelo pagamento nos delitos fiscais. (SCHMMIDT, 2003).

Percebe-se que as causas de extinção de punibilidade atendem aos critérios da política criminal adotada pelo legislador brasileiro.

Pode-se, também, observar que tanto no âmbito do Direito Penal como no âmbito do Direito Processual Penal existem causas extintivas de punibilidade, no primeiro caso em relação às próprias penas e no segundo caso, em relação às condições de procedibilidade (condições genéricas e específicas).

\section{Desenvolvimento da Legislação e da Jurisprudência}

A Lei no 8.137/90, que regula e tipifica, atualmente, os delitos fiscais, já chegou a prever em seu art. 14 a extinção da punibilidade. Pelo artigo, se o pagamento do tributo ou de seus acessórios fosse realizado antes do recebimento da denúncia, haveria a possibilidade de ocorrer à extinção de punibilidade. Porém, o referido artigo foi revogado pela Lei no 8.383/91.

Posteriormente, a Lei n. 9.249/95 voltou a dispor sobre o instituto da extinção de punibilidade em seu art. 34. Desta forma, a partir de então, com o pagamento do tributo até o recebimento da denúncia, haveria a possibilidade de extinção de punibilidade.

O STJ estendeu o benefício às situações em que ocorre o parcelamento do débito tributário, antes do 
recebimento da denúncia, no julgado do $\mathrm{HC}$ n.9.909/PE:

CRIMINAL. RECURSO EM HABEAS CORPUS. CRIME CONTRA A ORDEM
TRIBUTÁRIA. PARCELAMENTO ANTERIOR A DENÚNCIA. DESNECESSIDADE
DO PAGAMENTO INTEGRAL. RECURSO PROVIDO. I. Uma vez deferido o
parcelamento, em momento anterior ao recebimento da denúncia, verifica-se a extinção da
punibilidade prevista no art. 34 da Lei no 9.249/95, sendo desnecessário o pagamento
integral do débito para tanto. II. Recurso provido para conceder a ordem, determinando o
trancamento da ação penal movida contra o paciente.
(STJ - RHC: 12383 SP 2002/0008050-2, Relator: Ministro GILSON DIPP, Data de
Julgamento: $19 / 02 / 2004$, T5 - QUINTA TURMA, Data de Publicação: <!-- DTPB:
20040405<br>--> DJ 05/04/2004 p. 275 ).
ser regulamentada pela Lei no $9.964 / 00$ em seu art. 15 , porém, o legislador considerou
que, no caso de parcelamento antes da denúncia, não haverá extinção de punibilidade, mas sim a suspensão da pretensão punitiva estatal.

Mas, a Lei no 10.684 de 2003, em seu art. 9, caput, considerou a suspensão da punibilidade no caso de parcelamentos, o legislador não se preocupou com o aspecto temporal, podendo ocorrer à suspensão antes ou depois do recebimento da denúncia.

Já a extinção de punibilidade, pelo pagamento integral da dívida tributária, foi prevista no art. $9^{\circ}, \$ 2^{\circ} \mathrm{e}$ como, neste caso, o legislador não fez nenhuma menção sobre o aspecto temporal, considerou-se que a extinção poderia ocorrer antes ou depois do recebimento da denúncia. In verbis:

Art. $9^{\circ} \$ 2^{\circ}$ Extingue-se a punibilidade dos crimes referidos neste artigo quando a pessoa jurídica relacionada com o agente efetuar o pagamento integral dos débitos oriundos de tributos e contribuições sociais, inclusive acessórios. (BRASIL, Lei no 10.684, de 2003).

De 2003 a 2010 outras leis surgiram com criações de programas de parcelamento de débitos tributários e criando regulamentos diferenciados, trazendo muitas discussões e controvérsias.

Em 2011 foi publicada a Lei no 12.382 que em seu art. 6, $\$ 4^{\circ}$, regulamentou a suspensão da pretensão punitiva pelo parcelamento do delito fiscal, porém, fez menção ao aspecto temporal, mencionando que haverá suspensão se o parcelamento for feito antes do recebimento da denúncia. Mas, não alterou a regra do pagamento integral do tributo devido e sua consequente extinção de punibilidade (que consta na Lei no 10.684/03, art. 9 , $\left.\$ 2^{\circ}\right)$

Lei no 12.382/11: Art. $6^{\circ} \mathrm{O}$ art. 83 da Lei no 9.430 , de 27 de dezembro de 1996, passa a vigorar acrescido dos seguintes $\$ \$ 1^{\circ}$ a $5^{\circ}$, renumerando-se o atual parágrafo único para $₫ 6^{\circ}$ : "Art. 83.

\10 Na hipótese de concessão de parcelamento do crédito tributário, a representação fiscal para fins penais somente será encaminhada ao Ministério Público após a exclusão da pessoa física ou jurídica do parcelamento.

$\$ 2^{\circ}$ É suspensa a pretensão punitiva do Estado referente aos crimes previstos no caput, durante o período em que a pessoa física ou a pessoa jurídica relacionada com o agente dos aludidos crimes estiver inclú́da no parcelamento, desde que o pedido de parcelamento tenha sido formalizado antes do recebimento da denúncia criminal.

$\$ 3^{\circ}$ A prescrição criminal não corre durante o período de suspensão da pretensão punitiva. 
$\$ 4^{\circ}$ Extingue-se a punibilidade dos crimes referidos no caput quando a pessoa física ou a pessoa jurídica relacionada com o agente efetuar o pagamento integral dos débitos oriundos de tributos, inclusive acessórios, que tiverem sido objeto de concessão de parcelamento. $\$ 5^{\circ} \mathrm{O}$ disposto nos $₫ \S 1^{\circ}$ a $4^{\circ}$ não se aplica nas hipóteses de vedação legal de parcelamento. $\int 6^{\circ}$ As disposições contidas no caput do art. 34 da Lei $n^{\circ} 9.249$, de 26 de dezembro de 1995, aplicam-se aos processos administrativos e aos inquéritos e processos em curso, desde que não recebida a denúncia pelo juiz." (BRASIL, Lei no 12.382, de 2011). Grifo nosso.

O parcelamento em si não é causa de extinção de punibilidade, mas sim, causa de suspensão, pois, somente a quitação integral do débito é que irá proporcionar a extinção de punibilidade 3 .

No entanto, ocorreram controvérsias no meio doutrinário e jurisprudencial, nesse sentido, Machado dispôs:

Recentemente, quando se imaginava pacificado o assunto, a Lei n. 12.382, de 25 de fevereiro de 2011, veio com novos dispositivos que poderão suscitar controvérsias. Em seu art. $6^{\circ}$ alterou a redação do art. 83, da Lei n. 9.430, de 27 de dezembro de 1996, inserindo no mesmo cinco parágrafos, com a renumeração do parágrafo único. O caput deste art. 83 já tivera sua redação alterada pela Lei n. 12.350, de 20 de dezembro de 2010. (...) Considerando que a regra do $\$ 6^{\circ}$, que antes da Lei n. 12.350/2010 estava no parágrafo único, já havia sido alterado no sentido de se admitir a extinção da punibilidade pelo pagamento feito a qualquer tempo, agora será suscitada a questão de saber se o fato de haver sido expressamente mantida deve ser entendido como uma reedição e, assim, voltaríamos à situação na qual o pagamento somente extinguiria a punibilidade se feito antes do recebimento da denúncia. (MACHADO, 2011, p. 387).

Muitas decisões judiciais diferenciam com clareza as consequências do pagamento integral do tributo devido e o parcelamento do tributo. Exemplos de decisões:

PROCESSO PENAL. HABEAS CORPUS. INQUÉRITO POLICIAL. CRIME DE SONEGAÇÃO FISCAL. DEPÓSITO JUDICIAL DO TRIBUTO PARA OPOSIÇÃO DE EMBARGOS EM EXECUÇÃO FISCAL NÃO ACARRETA A EXTINÇÃO DA PUNIBILIDADE. PEDIDO DE ARQUIVAMENTO DO INQUÉRITO POLICIAL FEITO PELO PARQUET INDEFERIDO PELO JUIZ. APLICAÇÃO DO ART. 28 DO CÓDIGO DE PROCESSO PENAL. DECISÃO MANTIDA. 1. O art. 28 do Código de Processo Penal prevê o controle do arquivamento de inquérito policial pelo Judiciário em homenagem ao princípio da obrigatoriedade da ação penal. Desse modo, embora o Ministério Público seja o titular da ação penal, não cabe a ele a exclusiva deliberação acerca do oferecimento de denúncia ou do arquivamento do inquérito, devevendo submeter seu pedido ao juiz, o qual poderá acatá-lo ou não. 2. 0 art. 9 , $\$ 2^{\circ}$, da Lei $n^{\circ} 10.684 / 03$, possibilita a extinção da punibilidade a qualquer tempo, em virtude do pagamento integral do débito, ou a suspensão da pretensão punitiva, em virtude do parcelamento do débito tributário. Não ocorrência na hipótese. 3. No crime de sonegação fiscal, o depósito judicial da quantia alcançada para fins de oposição de embargos à execução fiscal acarreta a suspensão da exigibilidade do tributo, cujos efeitos estão reduzidos à esfera cível. No juízo penal, somente haverá a extinção da punibilidade com o pagamento do débito tributário na forma do art. $9^{\circ}, \$ 2^{\circ}$, da Lei no $10.684 / 03$, o qual não ocorreu na hipótese. 4. A existência ou não de justa causa para a instauração de ação penal envolve matéria probatória, cuja

\footnotetext{
${ }^{3}$ Sobre a Lei no 12.382/11, salutar a observação que a referida lei possui uma grave mácula relativa ao seu procedimento legislativo, pois veiculou num mesmo texto legislativo matéria atinente a salário mínimo e crimes tributários, portanto, objetos completamente diversos, com explícita ofensa à Lei Complementar n. 95/98, a qual prescreve em seu art. $7^{\circ}$ que cada norma tratará de um único objeto e não conterá matéria estranha a seu objeto ou a este vinculada por afinidade, pertinência ou conexão. (CAPEZ, 2012, p. 685).
} 
produção não é possível no estrito âmbito do habeas corpus. Assim, mostra-se prematuro o trancamento do inquérito policial. Grifo nosso.

(TRF-1 - HC: 4298 GO 0004298-84.2011.4.01.0000, Relator: JUIZ TOURINHO NETO, Data de Julgamento: 14/03/2011, TERCEIRA TURMA, Data de Publicação: e-DJF1 p.178 de 31/03/2011)

AGRAVO REGIMENTAL NO AGRAVO EM RECURSO ESPECIAL. CRIME TRIBUTÁRIO. ART. 1º, DA LEI No 8.137/90. PRINCÍPIO DA INSIGNIFICÂNCIA. NÃO CONSIDERAÇÃO. PARCELAMENTO DO DÉBITO FISCAL. VIGÊNCIA DA LEI No 10.826/03. RESCISÃO POR FALTA DE PAGAMENTO. NECESSIDADE DE PAGAMENTO INTEGRAL E EXTINÇÃO DA PUNIBILIDADE. NÃO OCORRÊNCIA. AGRAVO REGIMENTAL NÃO PROVIDO. 1. A Terceira Seção desta Corte Superior, no julgamento do REsp no 1.112.748/TO, representativo da controvérsia, firmou o entendimento de que é possível a aplicação do princípio da insignificância aos débitos tributários desde que o total do tributo ilidido não ultrapasse o patamar de R\$ 10.000,00 (dez mil reais) previstos no art. 20, da Lei no 10.522/02. 2. Hipótese em que o ora agravante obteve deferimento de parcelamento de seu débito tributário em 08/11/2006, com rescisão em 05/04/2008, por falta de pagamento, restando um saldo devedor de R $\$$ 8.991,96 (oito mil, novecentos e noventa e um reais e noventa e seis centavos). 3. A Terceira Seção do Superior Tribunal de Justiça, na vigência da Lei no 9.249/95, interpretando o seu art. 34, firmou o entendimento de que o parcelamento do débito tributário levava à extinção da punibilidade desde que efetuado antes do recebimento da denúncia. Entretanto, efetuado o parcelamento do débito tributário na vigência da Lei no 10.826/03, como ocorre in casu, aplica-se o disposto no seu art. $9^{\circ}$, afastando-se a incidência da Lei $n^{\circ}$ 9.249/95, ficando condicionada a extinção da punibilidade ao seu pagamento integral, que, na espécie não ocorreu, impedindo qualquer consideração sobre a incidência do princípio da insignificância. 4. Agravo regimental não provido. Grifo nosso.

(STJ - AgRg no AREsp: 401904 SP 2013/0327374-4, Relator: Ministro MOURA RIBEIRO, Data de Julgamento: 06/02/2014, T5 - QUINTA TURMA, Data de Publicação: DJe 12/02/2014)

Em relação ao momento da quitação integral do débito tributário, as decisões não são pacificadas. A Lei $n^{\circ} 10.684 / 03$, art. 9, $\$ 2^{\circ}$ (em vigência) dispõe que haverá a extinção de punibilidade, caso o pagamento seja feito antes ou depois do recebimento da denúncia, entende-se, portanto, até o trânsito em julgado da sentença condenatória, sendo extinta a pretensão punitiva do Estado. Assim, não há que se entender que se o pagamento integral do débito for feito após o trânsito em julgado, haverá a aplicabilidade do instituto, pois, estaria ocorrendo à extinção da pretensão executória e não da pretensão punitiva do Estado. Além do mais, se assim fosse, o processo penal seria inócuo e a ação penal teria função de mero instrumento de arrecadação de tributo, conforme decisão proferida pelo STJ em 2015:

EXECUÇÃO PENAL. HABEAS CORPUS. CRIME CONTRA A ORDEM TRIBUTÁRIA. PAGAMENTO INTEGRAL DO DÉBITO TRIBUTÁRIO. SENTENÇA TRANSITADA EM JULGADO. EXTINÇÃO DA PUNIBILIDADE. ART. 9, DA LEI N. ${ }^{\circ}$ 10.684/03. IMPOSSIBILIDADE. CONSTRANGIMENTO ILEGAL. NÃO OCORRÊNCIA. RECURSO DESPROVIDO. 1. O art. 9o da Lei n. ${ }^{\circ} 10.684 / 03$ trata da extinção da punibilidade pelo pagamento do débito tributário, antes do trânsito em julgado da condenação, uma vez que faz menção expressa à pretensão punitiva do Estado. Não há que se falar em extinção da punibilidade pelo pagamento, quando se trata de pretensão executória, que é o caso dos autos. 2. Recurso ordinário em habeas corpus desprovido. Grifo nosso.

(STJ - RHC: 56665 PE 2015/0033022-0, Relator: Ministra MARIA THEREZA DE ASSIS 
MOURA, Data de Julgamento: 19/03/2015, T6 - SEXTA TURMA, Data de Publicação: DJe 27/03/2015)

Em 2016 o Tribunal Regional Federal (TRF-3), julgou de maneira oposta. Entendendo que à quitação integral do débito tributário ocorrendo em qualquer momento, levará à extinção de punibilidade, ou seja, mesmo após o trânsito em julgado da condenação, porém, os efeitos secundários da condenação serão mantidos, por exemplo, a reincidência, conforme ementa da decisão:

HABEAS CORPUS. CRIME CONTRA A ORDEM TRIBUTÁRIA. PAGAMENTO INTEGRAL DO DÉBITO APÓS O TRÂNSITO EM JULGADO. EXTINÇÃO DA PUNIBILIDADE. ORDEM CONCEDIDA. Consta que o paciente foi definitivamente condenado pela prática do crime previsto no artigo $1^{\circ}$, incisos I, II e III, da Lei no 8.137/90, na forma do artigo 71 do Código Penal, à pena de 4 anos de reclusão e 22 dias-multa. Após o trânsito em julgado, os impetrantes comprovaram o pagamento integral dos débitos que deram ensejo à condenação do paciente nos autos da ação penal originária. $\underline{\mathrm{O} \text { pagamento }}$ integral do débito tributário, a qualquer tempo, mesmo após o trânsito em julgado, enseja a extinção da punibilidade do crime previsto no artigo $1^{\circ}$ da Lei 8.137/90. Considerando que apenas a pretensão executória é atingida pela causa extintiva da punibilidade ocorrida após o trânsito em julgado da sentença, subsistem os efeitos secundários da condenação, como, por exemplo, a reincidência. Ordem concedida. Grifo nosso.

(TRF-3 - HC: 00284795620154030000 SP 0028479-56.2015.4.03.0000, Relator: DESEMBARGADOR FEDERAL JOSÉ LUNARDELLI, Data de Julgamento: 02/02/2016, DÉCIMA PRIMEIRA TURMA, Data de Publicação: e-DJF3 Judicial 1 DATA: $12 / 02 / 2016)$

Mas, a controvérsia continua em 2016, pois, a decisão do TJ-PR seguiu o mesmo entendimento do STJ e não o entendimento TRF-3:

DECISÃO: ACORDAM os integrantes da Primeira Câmara Criminal do Tribunal de Justiça do Estado do Paraná em composição integral, por unanimidade de votos, em JULGAR IMPROCEDENTE a revisão criminal. EMENTA: REVISÃO CRIMINAL CRIME CONTRA A ORDEM TRIBUTÁRIA (ART. 1-I-II DA LEI N. 8.137/90)PRETENDIDA EXTINCÃO DA PUNIBILIDADE PELO PAGAMENTO INTEGRAL DO DÉBITO - INADMISSIBILIDADE - TRÂNSITO EM JULGADO DA CONDENAÇÃO - INAPLICABILIDADE DO ART. 9० DA LEI N. ${ }^{\circ}$ 10.684/03 EM RELAÇÃO À PRETENSÃO EXECUTÓRIA - PEDIDO IMPROCEDENTE. (Grifo nosso).

(TJ-PR - RVCR: 14263268 PR 1426326-8 (Acórdão), Relator: Telmo Cherem, Data de Julgamento: 11/02/2016, 1a Câmara Criminal em Composição Integral, Data de Publicação: DJ: 1745 23/02/2016)

No entanto, há decisões do STF que admitiram a extinção da punibilidade pelo pagamento mesmo após a condenação. Como nos Embargos de Declaração na Ação Penal 516:

Ementa: embargos de declaração na ação penal originária. Crimes de apropriação indébita previdenciária e de sonegação de contribuição previdenciária (inciso i do $\$ 1^{\circ}$ do art. 168-a e inciso iii do art. 337-a, ambos do código penal). Réu condenado à pena-base de 3 (três) anos de reclusão e 30 (trinta) dias-multa, para cada delito, que, na ausência de circunstâncias atenuantes e agravantes e aumentada de 1/6 (um sexto) ante a continuidade delitiva, foi tornada definitiva em 3 (três) anos e 6 (seis) meses, e 30 dias multa. Pena que, somada, devido ao concurso material, totalizou 7 (sete) anos de reclusão e 60 (sessenta) dias multa, fixados no valor unitário de $1 / 2$ (um meio) salário mínimo, vigente em agosto de 2002 (término da continuidade delitiva), atualizados monetariamente desde então. Embargos de 
Declaração. Extinção da punibilidade em face do pagamento integral do débito fiscal e ocorrência da prescrição retroativa da pretensão punitiva do estado, supervenientes à sessão de julgamento e antes da publicação do acórdão condenatório. Embargos providos. (Grifo nosso).

(AP 516 - ED/DF - Distrito Federal. Bem. Decla. Na Ação Penal. Relator: Min. Ayres Britto. Relator p/ Acórdão: Min. Luiz Fux. Julgamento: 05/12/2013. Órgão Julgador: Tribunal Pleno).

Como, também, decisão semelhante foi disposta na Ação Penal no 613/TO:

QUESTÃO DE ORDEM NA AÇÃO PENAL. CONSTITUCIONAL. PROCESSUAL PENAL. CRIME DE APROPRIAÇÃO INDÉBITA PREVIDENCIÁRIA. SUSPENSÃO DA PRETENSÃO PUNITIVA E EXTINÇÃO DA PUNIBILIDADE. PARCELAMENTO E PAGAMENTO DO DÉBITO ANTES DO TRÂNSITO EM JULGADO DA SENTENÇA PENAL CONDENATÓRIA: EXTINÇÃO DA PUNIBILIDADE. PRECEDENTES. 1. A jurisprudência deste Supremo Tribunal é firme no sentido da possibilidade de suspensão da pretensão punitiva e de extinção da punibilidade nos crimes de apropriação indébita previdenciária, admitindo a primeira se a inclusão do débito tributário em programa de parcelamento ocorrer em momento anterior ao trânsito em julgado da sentença penal condenatória e a segunda quando o débito previdenciário for incluído - e pago - no programa de parcelamento ordinário de débitos tributários. Precedentes. 2. Questão de ordem resolvida no sentido de declarar extinta a punibilidade do réu em relação ao crime de apropriação indébita previdenciária, pela comprovação da quitação dos débitos discutidos no presente processo-crime, nos termos das Leis ns. 10.684/03 e 11.941/09. (Grifo nosso).

(STF - AP: 613 TO, Relator: Min. CÁRMEN LÚCIA, Data de Julgamento: 15/05/2014, Tribunal Pleno, Data de Publicação: ACÓRDÃO ELETRÔNICO DJe-107 DIVULG 0306-2014 PUBLIC 04-06-2014)

Márcio André Lopes Cavalcante explica as decisões do STF da seguinte forma:

O pagamento do tributo, a qualquer tempo, extingue a punibilidade do crime tributário. Defende que o art. $9^{\circ}$ da Lei n. 10.684/2003 não foi revogado e continua em vigor. Ao contrário das leis de ns. $11.941 / 2009$ e 12.382/2011, a Lei n. 10.684/2003 trata de pagamento direto (e não de pagamento após parcelamento). Assim, o pagamento integral implica a extinção da punibilidade por força do $\$ 2^{\circ}$, do art. $9^{\circ}$ da Lei n. 10.684/2003. (CAVALCANTE, 2014, p. 804).

Em suma, o artigo 9o da Lei n. ${ }^{\circ}$ 10.684/2003 possibilita que o contribuinte (pessoas físicas ou sócios de pessoas jurídicas) acusado por crime tributário efetue o pagamento integral do tributo devido, pela Lei antes ou depois do recebimento da denúncia e por algumas decisões judiciais mesmo depois do trânsito em julgado da sentença condenatória, e requeira o benefício do instituto da extinção de punibilidade, bem como, poderá o contribuinte aderir ao parcelamento do valor do tributo devido, antes do recebimento da denúncia, requerendo a suspensão da pretensão punitiva do Estado até o final do pagamento integral e, portanto, quitando o parcelamento de forma integral, poderá requerer a extinção pela quitação da dívida.

Salientando, que todas as dívidas tributárias, sejam federais, estaduais ou municipais, são passíveis de serem pagas, seja por pagamento integral ou parcelado.

Finalizando o Capítulo, a pesquisa delimitou a análise dos crimes contra a Ordem Tributária no que diz respeito ao instituto da extinção de punibilidade pelo pagamento do tributo nos delitos fiscais. 
Assim, com o objeto de estudo especificado e analisado, parte-se para o segundo Capítulo que tem a incumbência de apresentar a análise da ciência da Criminologia, em harmonia com a proposta de pesquisa, ou seja, a análise da extinção de punibilidade pelo pagamento do tributo sob a visão crítica da Criminologia por meio de sua teoria de etiquetamento.

\section{CRIMINOLOGIA CRÍTICA}

No início do Século XX houve uma separação entre as ciências do Direito Penal e da Criminologia. A primeira seguiu o curso de ciência dogmática e normativa, a ciência de "dever-ser" (mundo dos valores), a segunda como ciência dos estudos do criminoso, das causas do crime, da sociedade criminógena, a ciência do "ser" (mundo real, empírico).

A política criminal para ser elaborada deve atentar-se aos estudos desenvolvidos pelas duas ciências, e não apenas por estas, mas, também, por outras ciências, como a psicologia criminal, a sociologia criminal, biologia criminal, entre outras ciências conhecidas como auxiliares.

Antes de se adentrar aos conceitos e características da Criminologia crítica, faz-se necessária a apresentação de breve relato sobre a evolução histórica da ciência da Criminologia, apontando-se alguns estudiosos que foram os precursores da ciência, não havendo o objetivo de esgotamento do tema, pois, ocorreria um afastamento dos intuitos da pesquisa monográfica.

\section{História da Criminologia}

\section{$\underline{2.1 .1 \text { Da Antiguidade - precursores da Criminologia }}$}

Para a compreensão do período da Escola Positivista, que define o surgimento da ciência da Criminologia e seus criadores, é fundamental, inicialmente, o conhecer de alguns dos estudiosos da Antiguidade que foram considerados precursores da ciência da Criminologia. A etapa pré-científica da Criminologia é disposta por Antonio García-Pablos de Molina e Luiz Flávio Gomes:

Antes da publicação da famosa obra lombrosiana, que costuma ser citada como "certidão de nascimento" da Criminologia empírica "científica", já existiam numerosas "teorias" sobre a criminalidade. ( ... Nesta "etapa pré-científica" havia dois enfoques claramente distintos, em razão do método de seus patrocinadores: por um lado, o que se pode denominar "clássico" (produto das idéias do Iluminismo, dos Reformadores e do Direito Penal "clássico": modelo que se vale de um método abstrato, dedutivo e formal); de outro, o que se pode qualificar de "empírico", por ser desta classe as investigações sobre o crime, realizadas de forma fragmentária por especialistas das mais diversas procedências (fisonomistas, frenólogos, antropólogos, psiquiatras, etc.), tendo todos eles em comum o fato de que substituem a especulação, a intuição e a dedução pela análise, observação e indução (método empíricoindutivo). (MOLINA; GOMES, 2002, p. 175). 
Conforme estudos feitos pelos autores, mesmo antes do Código Hamurabi, Confúcio já demonstrava conhecer o que seria uma das preocupações da Criminologia: o gravame da pena.

Os estudos práticos para a averiguação das questões biopsíquicas dos delinquentes já, no Século VI a.C., eram realizados por estudiosos da Grécia Antiga que dissecavam animais para realizarem tais experiências e pesquisavam o cérebro humano para alcançar uma correlação com as condutas delitivas. Os gregos acreditavam que o ser homem possuía traços animais e Divinos, devendo haver um equilíbrio, pois, com o desequilíbrio surgiria o ser homem doente. (FERNANDES; FERNANDES, 2002).

O considerado pai da medicina, Hipócrates, acreditava que o crime tinha origem na loucura, isto é, o homem criminoso era um ser insano. Sócrates acreditava que os indivíduos criminosos deveriam receber instrução e formação de caráter, para que não voltassem a delinquir. Platão, por sua vez, afirmava que o motivo da delinquência era o "ouro", pois, acreditava que os fatores econômicos e sociais levavam a ocorrência criminal (A República), assim, onde houvesse o pobre, haveria o delinquente. Aristóteles afirmava que a miséria trazia o delito (A Política) e que o homem era submetido à razão que controla sua sensibilidade. O filósofo estudou o caráter dos delinquentes e a tendência à reincidência. (A Retórica). (FERNANDES; FERNANDES, 2002).

\section{Da Idade Média - precursores da Criminologia}

A Idade Média foi marcada pelo feudalismo e pelo desenvolvimento do cristianismo que vinculavam os estudos filosóficos.

Considerava-se o crime como um pecado que merecia, como consequência, ser punido e a tortura deveria ser utilizada como meio para se obter a confissão.

São Tomás de Aquino consagrou a expressão "dar a cada um, o que é seu” e firmou entendimento de que a pobreza é geralmente uma incentivadora à delinquência. Santo Agostinho acreditava que a pena deveria ser uma medida de defesa social, contribuindo com a mudança moral do delinquente, bem como, era um exemplo a todos os indivíduos. (FERNANDES; FERNANDES, 2002).

No período havia as chamadas "ciências ocultas", que eram a Astrologia, a Oftalmoscopia, a Metoposcopia, a Quiromancia, a Fisiognomia e Demonologia. Tais ciências ocultas levaram ao desenvolvimento da ciência da Criminologia.

Apenas para exemplificar, a Fisiognomia buscava entender o caráter da pessoa pelo exame dos traços fisionômicos e cranianos e a Demologia estudava os demônios e as influências nos indivíduos (estudos que influenciaram no período da Inquisição e no surgimento posterior da Psiquiatria). 


\section{Da Idade Moderna - precursores da Criminologia}

O Iluminismo, o chamado século das luzes (apogeu no Século XVIII), contribuiu com o surgimento das escolas penais (Escola Clássica, Escola Positivista, Escola Moderna, entre outras).

$\mathrm{Na}$ época existia uma arbitrária e imparcial justiça. Os métodos utilizados para a efetivação da suposta justiça eram violentos e cruéis. Havia uma péssima estrutura de recolhimento dos possíveis culpados. Assim, tanto os humanistas como os iluministas se contrapõem a estas condições inadequadas e desumanas.

Foram muitos os filósofos que participaram ativamente deste movimento renovador.

Montesquieu defendia que o legislador deveria se atentar para a prevenção de delito (pena como reeducação) e não, apenas, buscar castigar o delinquente. ("L'esprit des lois"). Rousseau afirmava que o Estado deveria ser organizado para não existir tantos delinquentes (Contrato Social), assegurava que os grandes delitos eram cometidos por causa da "miséria" (Enciclopédia) e, ainda, criticou o conceito de propriedade ("isto é meu"). (Discursos sobre a Origem e o Fundamento da Desigualdade entre os homens). Voltaire não aceitava a aplicação de pena de morte, as penas cruéis e as torturas. Lutou pela reforma das prisões. Salientava que o roubo e o furto eram infrações penais cometidas por pobres. Beccaria afrontou os costumes penais, rebelou-se contra a justiça criminal aplicada na época. Defendeu a humanidade. Acreditava que a pena não deveria atormentar o acusado, mas sim, impedi-lo a delinquir novamente, bem como, a servir de exemplo para outros. Como também, defendia que o roubo era ocasionado, normalmente, pelo desespero causado pela miséria. Foi um precursor fundamental da Escola Clássica do Direito Penal. (Dos delitos e das penas). (FERNANDES; FERNANDES, 2002).

Bentham, considerado o criador da Filosofia Utilitarista, defendeu uma doutrina inserida de estratégicas para a profilaxia ou prevenção de criminalidade. Rolandis, em 1835, foi o primeiro a submeter um criminoso a uma necropsia. Lucas tratou dos caracteres anormais do criminoso, o que fundamentou a posterior tese defendida por Lombroso. (Sulla natura Morbosa Del delito). Felipe Pinel, tido como o pai da psiquiatria Moderna, modificou a forma de tratamento dos loucos. Recomendava que devia haver tratamento adequado e não violências que acabavam por agravar a doença. (FERNANDES; FERNANDES, 2002).

\section{Da Escola Positiva - Do surgimento da Ciência da Criminologia}

Por volta do final do século XVIII, começaram a surgir às escolas penais criminológicas.

A primeira Escola Sociológica do Crime foi a Escola Clássica que teve surgimento pela influência do Iluminismo italiano. Um dos grandes pensadores desta escola foi Marquês de Beccaria, que escreveu o livro "Dos Delitos e das Penas" em 1763, no qual criticava o sistema penal vigente a época (PENTEADO FILHO, 2013).

Cesare Beccaria, acompanhando o contratualismo de Rousseau, defendia que ocorria um rompimento 
com o pacto social no momento em que o indivíduo cometia um crime. (BECCARIA, 2001).

Na primeira metade do Século XX, surgiu à segunda escola penal criminológica, a Escola Positivista, embasada pelo positivismo e por conceitos objetivos. Esta corrente criminológica era diferenciada e influenciou na autonomia da Ciência da Criminologia. (MOLINA; GOMES, 2002).

A partir deste momento histórico, o surgimento da Escola Positivista, a Criminologia começou a se fortalecer como uma ciência independente, autônoma e emancipada, possuindo como objeto de estudo o delinquente.

Sendo uma ciência empírica, os estudiosos da Criminologia positivista não se contentaram com a definição causal delituosa como livre vontade de seu agente e iniciaram pesquisas direcionadas às questões antropológicas, biológicas e psicológicas, pois, acreditavam que influenciavam de maneira definitiva nas ações do delinquente. (MOLINA; GOMES, 2002).

Certamente, os estudiosos da nova Ciência da Criminologia queriam se diferenciar por meio de um caráter objetivista, o que não existia na Escola Clássica (livre-arbítrio), antecessora da Escola Positivista. Buscavam entender o agente delituoso de maneira específica, ou seja, não se tratava de livre-arbítrio do delinquente, mas sim de questões naturais. Entendiam que a própria estrutura corporal do delinquente (física e emocionalmente) já identificava a tendência à criminalidade.

Os autores Molina e Gomes comentam sobre o paradigma positivista da Criminologia o seguinte:

O fator aglutinante do positivismo criminológico foi o método empírico indutivo, que era sustentado pelos seus representantes frente à análise filosófico-metafísica que reprovavam na Criminologia Clássica. Referido método se ajustava ao esquema "causal-explicativo", que o positivismo propôs como modelo ou paradigma de "ciência". Os postulados da Escola Positiva podem ser sintetizados desta maneira: o delito é concebido como um fato real e histórico, natural, não como uma fictícia abstração jurídica; sua nocividade deriva não da mera contradição com a lei que ele significa, senão das exigências da vida social, que é incompatível com certas agressões que põem em perigo suas bases; seu objeto de estudo e compreensão são inseparáveis do exame do delinqüente e da sua realidade social; interessa ao positivismo a etiologia do crime, isto é, a identificação das causas como fenômeno, e não simplesmente a sua gênese, pois o decisivo será combatê-lo em sua própria raiz, com eficácia e, sendo possível, com programas de prevenção realista e científicos; a finalidade da lei penal não é restabelecer a ordem jurídica, senão combater o fenômeno social do crime, defender a sociedade; o positivismo concede prioridade ao estudo do delinqüente, que está acima do exame do próprio fato, razão pela qual ganha particular significação os estudos tipológicos e a própria concepção do criminoso como subtipo humano, diferente dos demais cidadãos honestos, constituindo esta diversidade a própria explicação da conduta delitiva. $\mathrm{O}$ positivismo é determinista, qualifica de ficção a liberdade humana e fundamenta o castigo na idéia da responsabilidade social ou na do mero fato de se viver em comunidade. Por último, propugna por um claro anti-individualismo inclinado a criar obstáculos à ordem social frente aos direitos do indivíduo e por diagnosticar o mal do delito com simplistas atribuições a fatores patológicos (individuais). (MOLINA; GOMES, 2002, p. 175).

Para o estudo da Criminologia Positiva serão apresentadas três fases do processo evolutivo histórico: $1^{\text {a }}$ fase - Antropologia Criminal - por Césare Lombroso; 2a fase - Sociologia Criminal - Enri Ferri e $3^{\mathrm{a}}$ fase - 
Conteúdo Jurídico (Política Criminal) - por Raphael Garófalo.

Pelo método empírico-indutivo, os autores das referidas fases buscavam classificar as possíveis causas do comportamento humano criminoso, objetivando a identificação do indivíduo delinquente, desviante e doente, bem como, descrevendo as formas de curá-lo, além de se preocupar com a defesa social diante destes "anormais" (BARATTA, 2002, p. 37-39).

\section{1a Fase - da Antropologia Criminal}

Cesare Lombroso (1835-1909) foi o idealizador da Antropologia Criminal. A ideia, em um contexto geral, retirava o Direito Penal de sua condição abstrata, ao contrário da Escola Clássica, colocando-a em sua própria concretude por verificações objetivas em relação ao criminoso.

Lombroso era um cientista italiano, médico psiquiatra, antropólogo, cirurgião e professor universitário. Por suas análises empíricas encontrou vários sinais físicos e psíquicos no delinquente objeto de estudo, considerando-o como criminoso nato em determinados casos. Acreditava que existiam características físicas que identificavam o verdadeiro criminoso (que para Lombroso, o verdadeiro criminoso era o nato), como: maxilar inferior específico, molares proeminentes, sobrancelhas avantajadas, orelhas grandes e deformadas, grande envergadura de braços, mãos e pés e dessimetria corporal. Ainda, em outros aspectos, o criminoso nato não era tão sensível à dor, tinha alto grau de crueldade, não gostava de trabalhar e era possuidor de muita instabilidade emocional, desenvolvia-se de forma precoce na sexualidade, entre outras características. (MOLINA; GOMES, 2002).

Molina e Gomes explicam que:

A contribuição principal de Lombroso para a Criminologia não reside tanto em sua famosa tipologia (onde destaca a categoria do "delinqüente nato") ou em sua teoria criminológica, senão no método que utilizou em suas investigações: o método empírico. Sua teoria do "delinqüente nato" foi formulada com base nos resultados de mais de quatrocentas autópsias de delinqüentes e seis mil análises de delinqüentes vivos, e o atavismo que, conforme seu ponto de vista caracteriza o tipo criminoso - ao que parece - contou com o estudo minucioso de vinte e cinco mil reclusos de prisões européias. (MOLINA; GOMES, 2002, p.191).

Posteriormente, Lombroso se retificou, considerando que nem todos os criminosos mostravam tais particularidades, criando outras opções de classificações.

Para o criminoso nato não havia saída, a não ser a prisão perpétua ou a pena de morte, desta forma, Lombroso influenciou em uma específica política criminal, objetivando conter as tendências criminais.

Mas, de maneira geral, Lombroso fez três classificações de criminosos: nato, ocasional e louco.

Em suas pesquisas acumulou vastos dados antropológicos pelas observações que realizava por meio de criminosos vivos e encarcerados, como, também, em criminosos mortos por meio de necropsias. 
Lombroso teve muito mérito, pois, foi o primeiro a desenvolver um estudo científico mais sério e organizado do crime e do criminoso, exatamente por este motivo que foi considerado o pai da Criminologia.

Como, também, as pesquisas realizadas ressaltaram, nos dias atuais, a importância das ciências auxiliares no âmbito criminal, com a Psicologia Criminal e a Biologia Criminal, ou seja, no criminoso há uma vida psíquica e uma orgânica que se intercalam e se complementam na conduta criminosa.

\section{$\underline{2^{a} \text { Fase - da sociologia Criminal }}$}

Enrico Ferri (1856-1929) foi um político socialista italiano e criminologista. Em suas pesquisas sobre a delinquência eram ressaltados os fatores sociológicos (obra Sociologia Criminal), porém, suas análises compreendiam, também, os fatores antropológicos e físicos como causas do delito. Foi o criador da Sociologia Criminal. (MOLINA; GOMES, 2002).

Ferri defendia a teoria jurídica da responsabilidade pessoal e não acreditava na liberdade da vontade psíquica do homem.

Para alguns estudiosos da Criminologia, foi Ferri o responsável pela expressão "criminoso nato" e não Lombroso.

Os delinquentes eram classificados por Ferri em cinco tipos: nato, louco, ocasional, habitual e passional. Molina e Gomes definem que:

Ferri é justamente conhecido por sua equilibrada teoria da criminalidade (equilibrada apesar do seu particular ênfase sociológico), por seu programa ambiciosa político criminal (substitutivos penais) e por sua tipologia criminal, assumida pela Scuola Positiva. Ferri censurou os "clássicos" porque renunciaram a uma teoria sobre a gênese da criminalidade, conformando-se a partir da constatação fática desta, uma vez ocorrida. Propugnava, em seu lugar, por um estudo "etiológico" do crime, orientando à busca científica de suas "causas". (MOLINA; GOMES, 2002, p.195).

3a Fase - do Conteúdo Jurídico (Política Criminal)

Raffaele Garófalo (1851-1934) foi jurista, magistrado e criminologista italiano. Criou o termo Criminologia como a ciência da criminalidade, do delito e da pena, apoiando-se nos estudos realizados por Lombroso, Ferri e por suas análises e pesquisas. (MOLINA; GOMES, 2002).

Garófalo defendia que os delitos ofendiam a moralidade e destacavam as anomalias de seus agentes, portanto, tratava-se de um assunto que não importava, apenas, aos juristas, mas, também, aos estudiosos da Sociologia.

Classificou os delitos como legais e naturais. Os legais variavam pela legislação de cada país, não violavam o senso de moral e não identificavam anomalias em seus agentes. Os naturais, ao contrário, ofendiam os 
sentimentos morais fundamentais, como os sentimentos de piedade e benevolência, bem como, as anomalias eram perceptíveis em seus agentes. (MOLINA; GOMES, 2002).

Apresentou as seguintes classificações de criminosos: assassinos, violentos ou enérgicos, ladrões e neurastênicos e cínicos.

Garófalo defendia a pena de morte. Sobre as ideias de Garófalo, Molina e Gomes discorrem:

A explicação da criminalidade dada por Garófalo, por sua vez, tem sem nenhuma dúvida conotações lombrosianas, por mais que conceda alguma importância (escassa) aos fatores sociais e que exija contemplação do fato e não somente das características do seu autor. Nega certamente, a possibilidade de demonstrar a existência de um tipo criminoso de base antropológica. Mas reconhece o significado e a relevância de determinados dados anatômicos (o tamanho excessivo das mandíbulas ou o superior desenvolvimento da região occipital em relação a frontal), ainda que diminua ou inclusive negue a interpretação lombrosiana dos estigmas. O característico da teoria de Garófalo é a fundamentação do comportamento e do tipo criminoso em uma suposta anomalia (não patológica) psíquica ou moral. Trata-se de um déficit na esfera moral da personalidade do indivíduo, de base orgânica, endógena, de uma mutação psíquica (porém não de uma enfermidade mental), transmissível por via hereditária e com conotações atávicas e degenerativas. (MOLINA; GOMES, 2002, p. 199).

Por fim, salutar a observação de que outras escolas, como a Escola Crítica (Von Liszt - pai da Política Criminal - Princípios de Política Criminal/1889), a Escola Neo-clássica (Manzini - Tratado de Direito Penal/1908), a Escola Neo-positivista (Asúa), como também as várias teorias sociais que foram desenvolvidas pelos estudiosos da criminalidade, contribuíram de maneira significativa ao desenvolvimento da Ciência da Criminologia da atualidade. (MOLINA; GOMES, 2002).

\section{Criminologia Crítica - Teoria do Etiquetamento}

Os estudos sobre os desvios de condutas e de suas consequentes penalizações realizados pelos marxistas e, posteriormente, pela Sociologia liberal, cultivaram o desenvolvimento da Criminologia crítica que é fundada em bases marxistas. Alessandro Baratta explica que:

Quando nos referimos ao movimento da criminologia crítica, apontamos o corpo teórico não homogêneo do pensamento criminológico que trabalha para a construção de uma teoria materialista, econômico-política, dos comportamentos socialmente negativos e da criminalização estatal. (BARATTA, 2002, p. 159).

Para a Criminologia crítica, as teorias liberais legitimam a ideologia penal seletiva, criando, assim, uma situação estigmatizante, não oferecendo uma postura puramente crítica quanto ao Direito Penal, apenas se envolvem com variadas relações socioeconômicas e estratificantes sociais, bem como, com a luta de classes ${ }^{4}$,

\footnotetext{
${ }^{4}$ David Garland esclarece sobre a luta de classes e o Direito Penal, em bases marxistas: "Direito penal é uma fonte de proteção e, ao mesmo tempo, de terror para as classes trabalhadoras. É indiscutível que alguns de seus aspectos envolvem uma função social, como proibir a violência e castigar os criminosos. No entanto, se a penalidade serve aos interesses de certa classe, o faz de uma maneira que assegura o apoio das classes subordinadas, protegendo os interesses que se consideram universais sobre os particulares. A esse passo, a chave para compreender o Direito Penal, em conflitos de classes, é reconhecer os modos em que se
} 
portanto, as teorias liberais não conseguiram desenvolver uma crítica efetiva ao sistema criminal. (BARATTA, 2002). A Criminologia crítica (ou nova Criminologia) surge a partir desta realidade.

A verificação do fenômeno criminal é realizada por análise macrossociológicas (onde há cumulação de riquezas e criminalidade) e análise microssociológicas (parte social que recebe o rótulo de criminoso), unindo as análises e pontuando a atuação das agências de poder, ou seja, os órgãos de poderes, bem como, a própria reação social.

Os objetos de estudo do fenômeno criminal passaram a serem outros a partir da Criminologia crítica. Os estudiosos críticos direcionaram suas análises no sistema penal, nos processos de criminalização e no sistema de reação social ao desvio.

Como já analisado, a Criminologia tradicional sempre desenvolveu seus estudos na pessoa do delinquente, nas causas do crime e, posteriormente, na vítima do delito. Agora, a Criminologia crítica vai além do criminoso e alcança o próprio sistema penal, suas formas de controle e seleção, como objetos de estudo.

Há, portanto, uma mudança de paradigma que causou um distanciamento teórico entre a Criminologia crítica e o Direito Penal. Nesse sentido, Baratta confronta a teoria jurídica da defesa social e a teoria sociológica da criminalidade:

O atraso da ciência jurídica em face do pensamento criminológico contemporâneo mais avançado é tal que, de fato, obriga a pensar que o mesmo não pode ser hoje recuperado através de uma crítica imanente, ou de uma autocrítica situada no interior da ciência jurídica. (BARATTA, 2002, p. 45).

Para o autor houve um avanço na atual crítica apresentada pela Criminologia, criando um conflito com as concepções e atuações do Direito Penal. No entanto, o autor salienta que deve haver integração entre as respectivas ciências, visando uma transformação no sistema penal que venha atender a realidade social, ou seja, um novo modelo de ciência penal integrada (dogmática jurídico-penal e o saber criminológico crítico). (BARATTA, 2002).

Baratta diz que:

A etiqueta "criminologia crítica" se refere a um campo muito vasto e não homogêneo de discursos que, no campo do pensamento criminológico e sociológico-jurídico contemporâneo, têm em comum uma característica que os distingue da criminologia "tradicional": a nova forma de definir objeto e os termos mesmos da questão criminal. A diferença é, também e principalmente, uma conseqüência daquilo que, também e principalmente, uma conseqüência daquilo que, utilizando a nomenclatura da teoria recente sobre "as revoluções científicas", onde pode ser definido como "mudança de paradigma" produzida na criminologia moderna. Sobre a base do paradigma etiológico a criminologia se

entrelaçam os interesses particulares com os interesses gerais". Tradução livre. In verbis: "(...) The criminal Law provides protection as well as 'terror' for the working classes, and there is undoubtedly a general social function involved in certain of its aspects such as the prohibition of violence and the punishment of predatory criminals. If penalty serves a class purpose it does so in a way which enlists support among the subordinate classes and which protects interests which are experienced as being universal rather than specific. The key to understanding criminal law in class terms is to appreciate the ways in which particular interests are interwoven with general ones".(GARLAND, 1990, p. 117). 
converteu em sinônimo de ciência das causas da criminalidade. (BARATTA, 2002, p. 209).

Em suma, a Criminologia crítica, representada por autores como Baratta, Hulsman, Pavarini e Bergalli, defende a ideia de que o Direito Penal e a política criminal não estão preparados para entender ou solucionar as diferenças econômicas da sociedade, portanto, precisam de outras ciências como, a Sociologia criminal e a Criminologia para alcançar conclusões satisfatórias.

\section{$\underline{\text { Teoria do Etiquetamento }}$}

Nos Estados Unidos (meados do século XX) se destacou a teoria do Labelling Approach, também conhecida por teoria do etiquetamento, rotulação ou reação social. A Teoria chegou à Alemanha e dois novos campos de estudo foram abordados: a "criminalidade de colarinho branco" e a "cifra oculta da criminalidade".

A teoria do etiquetamento é a base teórica da Criminologia crítica que, essencialmente, apoia-se em dois pontos contrapostos à Criminologia positivista: deslocamento do enfoque teórico do autor para as condições objetivas, estruturais, funcionais e o deslocamento do interesse etiológico do desvio para o conhecimento dos mecanismos que criam e aplicam as definições de crime e realizam os processos de criminalização. (DIAS; ANDRADE, 1997).

Na realidade, a teoria pode ser compreendida como uma transição da Criminologia clássica para a Criminologia crítica. Após o surgimento de várias teorias denominadas como criminológicas liberais, pela primeira vez, muda-se o objeto de estudo da Criminologia, de maneira crítica, e a teoria do etiquetamento determina a referida transição.

Pela teoria, a pergunta é alterada para: por que algumas pessoas são rotuladas pela sociedade e outras não?

E, ainda, as perguntas não são mais, quem é o criminoso? Ou como ele se torna criminoso? Mas sim, quem é definido como desviante? Que efeito decorre desta definição sobre o indivíduo? Em que condições este indivíduo pode se tornar objeto de uma definição? Ou, ainda, quem define quem?

Nesse sentido, Katie Arguello explica:

A criminologia positivista tradicional caracteriza-se por um paradigma etiológico, pelo qual a criminalidade se torna um atributo de determinados indivíduos ('anormais'), cuja propensão a delinqüir pode ser determinada pelas suas características biológicas e psicológicas (diferenciando-os dos indivíduos 'normais'), ou pelos fatores socioambientais a que estão submetidos. Essa criminologia etiológica (individual ou socioestrutural) parte das seguintes questões, entre outras: quem é o criminoso? Por que pratica o crime? Quais fatores socioambientais influenciam nas taxas de criminalidade? Enfim, busca as causas ou os fatores da criminalidade com o objetivo de individualizar as medidas adequadas para eliminá-los, intervindo sobre o comportamento do autor. A ideologia da defesa social ainda predomina na criminologia contemporânea, embora tenha sido questionada e praticamente substituída por um outro paradigma, o do labeling approach (paradigma da reação social). (ARGUELLO, 2005, p. 9). 
Para a teoria não há que se falar em criminosos naturais. Os fatores que criam o criminoso ou o crime estão ligados à própria sociedade em que são ou estão inseridos, bem como, pela política criminal, o ordenamento jurídico e o sistema penal que são aderidos ao Estado. E são os valores e costumes desta formação social que criam o rótulo daquele que se entende como criminoso, ou seja, determinando as condutas ilícitas. Portanto, há uma construção social. (BARATTA, 2011).

São estudadas as reações do controle social a partir do cometimento da infração penal, as consequências da criminalização (imputação de pena) e manutenção do status de criminoso que persegue o agente delituoso, impossibilitando sua recuperação.

É exatamente o rótulo (label) de criminoso que interessa a teoria do etiquetamento, pois, cria-se a estigmatização, impedindo a reeducação e a ressocialização do desviado.

A estigmatização pode gerar várias situações sociais, como, por exemplo, a chamada carreira criminal, ou seja, o ciclo de criminalidade é mantido, o delinquente se torna cada vez mais afastado da sociedade, de seus pares e os seus valores se destoam daquilo que é moral e aceito socialmente. Matar, roubar, fraudar passam a ser condutas "normais" diante de seus valores corrompidos ou nunca existentes.

É como se o delinquente pensasse: eu errei, paguei minha pena, mas, continuo sendo um criminoso e tratado como um criminoso, quais as oportunidades que vou ter? Nenhuma. E, certamente, estes estados psicológico, emocional e desestimulador irão influenciar nas suas próximas condutas.

Além do mais, o próprio delinquente pode aceitar e se convencer de que é realmente um criminoso, isto é, "veste" o rótulo designado a ele pelas criminalizações secundária e terciária, por mais que já tenha cumprido a sua criminalização primária, o cumprimento da pena que lhe foi imposta.

Portanto, o que visa à teoria da etiquetação é evitar o rótulo, a estigmatização, pois, é a única forma de ser interrompido o ciclo criminoso ou, de forma mais específica, evitar a reincidência do desviante.

Nesta ótica, Eugênio Raúl Zaffaroni e José Henrique Pierangeli discorrem:

Não somos todos igualmente 'vulneráveis' ao sistema penal, que costuma orientar-se por 'estereótipos' que recolhem os caracteres dos setores marginalizados e humildes, que a criminalização gera fenômeno de rejeição do etiquetado como também daquele que se solidariza ou contrata com ele, de forma que a segregação se mantém na sociedade livre. (ZAFFARONI; PIERANGELI, 1999, p. 73).

Em complemento, os autores se manifestam:

Os sistemas penais selecionam um grupo de pessoas dos setores mais humildes e marginalizados, os criminaliza e os mostra ao resto dos setores marginalizados como limites de seu 'espaço social'. Ao mesmo tempo, também parece que os setores que na estrutura de poder têm a decisão geral de determinar o sentido da criminalização têm também o poder de subtrair-se à mesma (ZAFFARONI; PIERANGELI, 1999, p. 74). 


\section{Seletividade do Sistema Penal}

A tese central defendida pela teoria do etiquetamento é que há um processo de seleção para a designação do perfil ideal de criminoso, ou seja, quem comete o delito do art. 155 do CP (furto) é um criminoso, mas, no entanto, algumas condutas ilícitas cometidas, não necessariamente determinam ao sujeito o rótulo de criminoso, como nos casos de delitos fiscais.

E não somente o cometimento do delito cria o rótulo de criminoso (criminalização primária), mas, principalmente às consequências de sua criminalização inicial (criminalizações secundárias), bem como, a sua rotulação social (criminalização terciária). (BARATTA, 2002).

Em outras palavras, pode-se ser compreendido na seguinte forma: a conduta ilícita cometida (desvio primário) pode ser consequência de vários fatores, sejam culturais, psicológicos, genéticos ou sócio-econômicos, mas, a reincidência (desvios seguintes) é uma consequência do etiquetamento ou rótulo atribuído ao agente desviante pela sociedade que o estigmatiza, ou seja, cria-se o estereótipo de eterno criminoso, fato que tende a impulsionar o desviante ao ciclo de criminalidade, ou seja, a carreira criminal.

Há duas correntes na teoria do etiquetamento, a primeira é entendida como radical e a segunda como moderada. Para a radical o controle social determina a criminalidade e para a moderada há a influência direta da justiça na formação do controle social da conduta desviada.

A criminologia crítica, seguindo a teoria do etiquetamento, defende a perspectiva macro-sociológica do desvio, opondo-se ao enfoque biopsicológico. A criminalidade se molda as estruturas sociais, ao desenvolvimento dos meios de produção e, por fim, a distribuição de riquezas. (BARATTA, 2002).

O comportamento criminoso ou a criminalidade são determinados pelo status social do indivíduo ou dos indivíduos que pertencem à determinada classe social. Pela perspectiva crítica não há mais seleção ontológica, mas sim, seleção social.

Os bens protegidos penalmente são determinantes para esta seleção do sistema penal, pois, definem quais as condutas ilícitas e os possíveis agentes delituosos que receberão os estigmas de criminosos.

Por esta perspectiva, há uma seleção de "clientes" do sistema penal, como também do sistema penitenciário, há uma distribuição desigual por causa dos interesses do sistema socioeconômico e da própria desigualdade social presente entre os indivíduos. (HASSEMER, 2000).

Como também explica Vera Regina Pereira de Andrade sobre a seletividade do Direito Penal:

Foi assim que a descoberta deste código social extralegal conduziu a uma explicação da regularidade da seleção (e das cifras negras) superadora da etiologia: da tendência a delinquir às maiores 'chances' (tendência) de ser criminalizado. A clientela do sistema penal é constituída de pobres, não porque tenham maior tendência para delinquir, mas precisamente porque têm maiores chances de serem criminalizados e etiquetados como delinquentes. As possibilidades (chances) de resultar etiquetado, com as graves 
consequências que isto implica, se encontram desigualmente distribuídas. (ANDRADE, 1997, p. 270).

Desta forma, há conclusões sobre o Direito Penal seletivo: o Direito Penal não defende a todos; as ofensas são punidas de forma desigual e fragmentária; a lei penal não é igual para todos e há desigualdade na distribuição dos status de criminoso aos indivíduos. (BARATTA, 2002).

A criminalidade de cunho econômico ou tributário é um bom exemplo, pois, é produzida pelos detentores do poder econômico/político, possui punição diferenciada e o delinquente é interpretado não com o rótulo de "criminoso".

Por essas construções ideológicas, há em todo o sistema penal injustiça por suas desigualdades e a solução é a inversão social dos valores em relação à distribuição de rendas.

O foco da Criminologia crítica, pelo até então analisado, são os processos de criminalização estruturados pela desigualdade, objetivando soluções à política criminal. Ressalta-se que as realidades dos processos estruturados pela desigualdade tornam a suposta igualdade do Direito Penal que, na realidade, é uma forma de controle social, em uma característica utópica, pois, o Direito Penal tende a privilegiar os interesses das classes dominantes. A conclusão é que, seguindo o raciocínio apresentado, a seleção para a designação da população criminosa, concentra-se na camada social dos infortunados, ou seja, nas classes sociais mais baixas. (BARATTA, 2002).

Percebe-se que a Criminologia crítica, pela teoria do etiquetamento, não tem o objetivo de explicar o fenômeno criminal como um todo, no entanto, destaca-se que, para os estudiosos críticos, a criminalidade é atribuída à pobreza. Assim, o objetivo é problematizar o fenômeno da criminalidade por análises políticas e econômicas.

O que a Justiça Penal faz é administrar a criminalidade, selecionando a clientela habitual que tem perfil adequado ao status de criminoso e, sem dúvida, o estado de miséria é um dos requisitos. Sendo o crime um subproduto que finaliza o processo legislativo desenvolvido pelas classes dominantes. (BARATTA, 2002).

Nesse sentido, conforme Zaffaroni e Pierangeli: "há os grupos que dominam e aqueles que são dominados" (1999, p. 60). Assim surge o controle social que tem o objetivo de limitar a conduta do indivíduo. Mas, os autores, também, salientam a realidade do Direito Penal como um "falso discurso de igualdade" (1999, p. 77). Não havendo um combate ativo para evitar condutas delinquentes, ou seja, não há políticas criminais que, realmente, criam meios de combater à criminalidade.

Conforme Baratta, é muito importante que a Criminologia crítica interfira na política criminal: "A ideia é exatamente esta: a busca de uma política criminal para os excluídos, para aqueles que são clientela preferencial dos processos perversos de seleção de criminalização”. (BARATTA, 1999, p. 200).

Para o autor deve se buscar um modelo político-criminal que desenvolva uma reforma penal que priorize 
a eficiência, a praticidade do sistema penal, bem como, a racionalidade crítica dinâmica que respeita a lógica da justiça social. Para Baratta, deve haver a complementaridade entre as ciências, que não podem atuar de forma isolada (1999).

Analisando as ideias apresentadas por Baratta, pode-se criar um exemplo com as medidas adequadas aos marginalizados, ou seja, àqueles que possuem os status de criminosos e que foram selecionados pelo critério da pobreza. Nestes casos, devem ser priorizadas políticas sociais que visem à prevenção primária do crime e não a simples retribuição ou repressão, esta que irá, apenas, fomentar reincidência. Priorizar a prevenção requer técnicas que atuem na origem do problema da criminalidade, isto é, nos momentos anteriores ao crime, objetivando a superação das posturas desviantes. Medidas estas que, inclusive, podem diminuir o custo alto do Direito Penal repressivo, retirando-lhe o caráter principal no âmbito da criminalidade, conferindo-lhe o seu real caráter subsidiário, de intervenção mínima e estritamente necessária. Certamente, o Estado, por esta visão democrática, deve atuar de maneira significativa no contexto das políticas sociais. Pelo raciocínio apresentado, como discorre Baratta: "O certo é que deve haver uma contração do sistema punitivo” (BARATTA, 1999, p. 205).

A contração do sistema punitivo representa a própria redução de aplicabilidade do Direito Penal, outro bom exemplo neste contexto, é a justiça restaurativa que se refere a uma justiça aplicada de maneira comunitária e pacificadora, visando à conciliação entre as partes e a reparação do dano causado. "Uma forma de justiça que proporciona custos baixos ao controle social”. (MOLINA; GOMES, 2000, p. 373).

Ainda sobre a contração do sistema punitivo, citado por Baratta, observa-se que em muitas situações e métodos utilizados, o sistema penal se torna ilegítimo e antidemocrático como, por exemplo, na falta de estrutura da Defensoria Pública que atua na defesa dos delinquentes selecionados ou nas violações dos Direitos Humanos como nas ocorrências de prisões ilegítimas, prazos não cumpridos, entre outras agressões que fazem parte do sistema penal. (BARATTA, 1999). Entende-se que a contração apresentada por Baratta evidencia exatamente tais ocorrências que devem ser evitadas, inclusive (e principalmente), para o fortalecimento do Estado Democrático de Direito, dos direitos e garantias fundamentais.

\section{CAPÍTULO III. PERSPECTIVA CRIMINOLÓGICA CRÍTICA EM RELAÇÃO AOS DELITOS FISCAIS - TEORIA DO ETIQUETAMENTO}

Certos indivíduos, que representam a sociedade, estipulam quais as condutas ilícitas que serão consideradas criminosas e suas respectivas sanções penais, bem como, decidem quem serão os merecedores do estigma de criminosos.

A definição se expressa diferenciando aqueles comportamentos que devem ser aceitos pela sociedade e aqueles que são desviantes. Ou seja, a definição legal indiretamente distingue o certo do errado. Assim, ocorre o 
poder do controle social.

Para a compreensão do fenômeno criminal, "leva-se em conta o sistema penal como um todo, analisando-se todas as instâncias oficiais que possuem a prerrogativa de atribuir a determinado infrator o status social de delinquente, tratando-se, portanto, do poder de controle social". (DIAS; ANDRADE, 1997, p. 44$54)$.

Dessa forma, a Criminologia crítica questiona o processo de definição da conduta proibida e as relações de poder que fazem determinados grupos deterem esta definição em suas mãos e, consequentemente, criarem e direcionarem uma reação social.

O paradigma da reação social, criada por esta seleção criminal, "é ponto de partida teórico para a construção das chamadas teorias sociais do conflito e é, ainda, ao fim e ao cabo, uma clara influência da teoria materialista, elaborada por Marx, pois compreende, pela primeira vez, um desdobramento do conflito de classes na esfera punitiva”. (BARATTA, 2002, p. 88-113).

Baratta especifica duas matrizes técnicas que formatam a criminalidade:

[...] Segundo o interacionismo simbólico, a sociedade - ou seja, a realidade social - é constituída por uma infinidade de interações concretas entre indivíduos, aos quais um processo de tipificação confere um significado que se afasta das situações concretas e continua a estender-se através da linguagem. Também segundo a etnometodologia, a sociedade não é uma realidade que se possa conhecer sobre o plano objetivo, mas o produto de uma 'construção social'. Obtida graças a um processo de definição e de tipificação por parte dos indivíduos e de grupos diversos. (BARATTA, 2002, p. 87).

Para o pesquisador Raúl Cervini "o delito econômico é produto da estrutura social em que se insere". É a estrutura socioeconômica de uma determinada sociedade que determina o delito e o condiciona. Há, portanto, uma relação fundamental entre sistema jurídico e sistema social. (CERVINI, 2003, p. 96-104).

Seguindo as ideias defendidas pelos autores ora citados, é perfeitamente notável que a reação social em relação aos delitos fiscais é diferenciada, pois, tais delitos são mais aceitos pela sociedade, ou seja, há mais tolerância da sociedade em relação à impunidade dos agentes criminosos, além de criarem o chamado "contágio hierárquico" (PIMENTEL, 1973).

\section{Crimes econômicos e a proteção do Sistema Penal}

Edwin Sutherland" criou o termo "crime do colarinho branco" e se destacou ao estudar os crimes econômicos.

\footnotetext{
${ }^{5}$ Edwin Hardin Sutherland (nascido em 13 de agosto de 1883 em Gibbon, Nebraska - falecido em 11 de Outubro de 1950 em Bloomington, Indiana) foi um renomado sociólogo estadunidense, que ganhou enorme reconhecimento pelo desenvolvimento da teoria criminal da associação diferencial e pela introdução do termo "crime do colarinho branco", entre outras contribuições. Formou-se nas matérias de sociologia e economia política na Universidade de Chicago, em 1913. Disponível em: <https://pt.wikipedia.org/wiki/Edwin_Sutherland>.Acesso em: 22 de jun. de 2016.
} 
Vera Regina Pereira de Andrade explica a pesquisa feita por Sutherland:

Já em seu clássico artigo White-Collar Criminality, Sutherland (1940) mostrava, com apoio de dados extraídos das estatísticas de vários órgãos americanos competentes em matéria de econômica e comércio, a impressionante proporção de infrações a normais gerais praticadas neste setor por pessoas colocadas em posição de alto prestígio social, bem como analisava as causas do fenômeno, sua ligação funcional com a estrutura social e os fatores que explicavam a sua impunidade. Posteriormente, em um artigo sugestivo intitulado Is 'White-Collar Crime' Crime?, Sutherland (1945), mostrando uma visão mais sofisticada da criminalidade do que a do paradigma etiológico - que antecipava até a visão do labelling - indagava precisamente se, devido àquela impunidade, eram crimes, os crimes de colarinho branco. [...] Por outro lado as proporções da criminalidade de colarinho branco, ilustradas por Sutherland e que remontavam os decênios precedentes, provavelmente aumentaram desde que ele escreveu seu artigo. Elas correspondem a um fenômeno criminoso característico não só dos Estados Unidos da América do Norte, mas de todas as sociedades. (ANDRADE,1997, p. 261).

Para Sutherland o sistema penal está ligado às estruturas materiais da sociedade e o autor defende que os indivíduos, respeitados e admirados pela sociedade, alocados nas mais altas camadas sociais, cometiam tantos crimes como aqueles desfavorecidos, taxados de marginais. (SUTHERLAND, 1983).

Assim, Sutherland critica as teorias criminológicas que ligavam os criminosos e suas condutas, por exemplo, ao estado de pobreza, ou seja, por etiologia patológica, pois, os ricos poderiam cometer delitos como os pobres.

Sutherland esclarece que:

A tese deste livro é que as patologias sociais e pessoais não são uma explicação adequada do comportamento do crime. As teorias gerais do comportamento criminoso que levam os seus dados de pobreza e as condições relacionadas a ela são inadequadas e inválido, em primeiro lugar, porque as teorias não se encaixam de forma consistente os dados de comportamento criminoso; e, segundo, porque os casos em que se baseiam essas teorias são uma amostra apartada de todos os atos criminosos. (SUTHERLAND, 1983, p. 05). ${ }^{6}$

Em relação aos "crimes do colarinho branco", o autor explica que tais agentes criminosos, dificilmente sofrem a persecução criminal e quase nunca acabam em estabelecimentos penitenciários, pois, há no sistema penal uma espécie de seleção (filtragem) em relação a estes criminosos que, normalmente, compõem as classes sociais mais altas e, além do mais, estes agentes não são estigmatizados ou marginalizados socialmente. Portanto, são as relações sociais-materiais que determinam a seleção criminal. (SUTHERLAND, 1983).

Nesse sentido, Daniel Viegas Barroso esclarece que:

No sistema capitalista de hoje, é fácil perceber que quem vai realmente preso, ou seja, aquele que sofre com o cárcere é o não-consumidor, o pobre, o negro, o desempregado, etc., enfim, todos aqueles esquecidos pela sociedade, pois é mais barato para o Estado prender do que fazer uma política de reintegração social. Estão rotulados pela comunidade, tanto que nunca

\footnotetext{
${ }^{6}$ Tradução livre. Nas palavras de Sutherland, a esse respeito, in verbis: "The thesis of this book is that social and personal pathologies are not an adequate explanation of crime behavior. The general theories of criminal behavior which take their data from poverty and the conditions related to it are inadequate and invalid, first, because the theories do not consistently fit the data of criminal behavior; and, second, because the cases on which these theories are based are a biased sample of all criminal acts. These two defects". (SUTHERLAND, 1983, p. 05).
} 
foram presos e torturados tantos negros e pobres como hoje em dia. (BARROSO, 2009, p.92).

No entanto, os agentes dos crimes econômicos são identificados como indivíduos que possuem respeito social e que são protegidos pelo sistema penal. A proteção surge na própria atividade legislativa, bem como, pelos meios de comunicação, fatos que realçam a desigualdade do Direito Penal (SUTHERLAND, 1983).

No que diz respeito à desigualdade dos tratamentos no Direito Penal, é salutar o questionamento da legitimidade da intervenção penal no caso da extinção da punibilidade pelo pagamento nos crimes tributários.

A lógica penal, no âmbito da política criminal, é questionada, por exemplo, no afastamento da persecução penal estatal, pelo pagamento integral da dívida tributária, principalmente, por serem delitos que são cometidos, em regra, pela classe social mais alta.

Em primeiro momento, justifica-se o instituto da extinção de punibilidade por sua constitucionalidade e legitimidade. No entanto, para o autor Baratta, o discurso, contaminado pela lógica punitiva positivada, omite os conflitos estruturais que envolvem o sistema jurídico-penal e oferece um olhar deformado da legitimidade penal. (BARATTA, 2002).

Para Newton Fernandes e Valter Fernandes:

Deixadas de lado as disputas casuais e as rivalidades ou rixas existem delitos que são próprios ou particulares de certas classes sociais endinheiradas, como, por exemplo, as infrações à lei sobre determinados impostos, as infrações contra o regime de sociedades anônimas, as falências fraudulentas, as concordatas, os delitos de usura, os delitos cometidos através de irregularidades em papéis, escrituração ou documentos de crédito contra o governo, etc. Esses tipos de delitos correspondem às cifras douradas da criminalidade, também chamados de 'crimes de colarinho branco' (White colar crime), ou seja, aqueles cujos criminosos possuem poder político, econômico ou social e que, por isso, suas atuações criminosas, na absoluta maioria dos casos, permanecem impunes, quase que representando uma condição de inimputabilidade situativa ou situacional. (FERNANDES; FERNANDES, 2002, p. 386387).

Pelas análises realizadas, não é indevida a conclusão de que o instituto de extinção de punibilidade pelo pagamento do tributo devido, sob a perspectiva criminológica, é uma inconcretude das disposições constitucionais em relação às finalidades da Ordem Econômica (art. 170 da CF), pela imunidade à delitos que causam danos concretos e significativos à sociedade em geral:

Artigo 170, CF: A ordem econômica, fundada na valorização do trabalho humano e na livre iniciativa, tem por fim assegurar a todos existência digna, conforme os ditames da justiça social, observados os seguintes princípios: I - soberania nacional. II - propriedade privada. III - função social da propriedade. IV - livre concorrência. V - defesa do consumidor. VI - defesa do meio ambiente, inclusive mediante tratamento diferenciado conforme o impacto ambiental dos produtos e serviços e de seus processos de elaboração e prestação. VII redução das desigualdades regionais e sociais. VIII - busca do pleno emprego. IX tratamento favorecido para as empresas de pequeno porte constituídas sob as leis brasileiras e que tenham sua sede e administração no País.

As ações criminosas dos delitos fiscais ocasionam fraudes contra o Poder Público, portanto, a sociedade é fraudada, tratando-se de delitos que violam bens coletivos e difusos. 
Apesar da seleção de crimes contra o patrimônio (furto, roubo, etc.), àqueles consumados pela classe marginalizada e desprovida de riquezas, são notáveis que os prejuízos financeiros de valores significativos resultam dos crimes de colarinho branco, econômicos e tributários. (SUTHERLAND, 1983).

Por Baratta há um sistema desigual e falho de distribuição de riquezas que gera consequências desastrosas à estabilidade social, mas, cabe a classe proletária o ônus da criminalidade, ou seja, os status de criminosos, no entanto, são os crimes cometidos pelas altas classes que geram os maiores prejuízos ao país, assim explica:

Vimos como isto não quer dizer, de modo algum, que o desvio criminal se concentre, efetivamente, na classe proletária e nos delitos contra a propriedade. A mesma criminologia liberal, com as pesquisas sobre a cifra negra, sobre a criminalidade do colarinho branco e sobre a criminalidade política demonstra, ao contrário, que o comportamento criminoso se distribui por todos os grupos sociais, que a nocividade social das formas de criminalidade próprias das classes dominantes e, portanto, amplamente imunes, é muito mais grave do que a de toda a criminalidade realmente perseguida. Por outro lado, o sistema das imunidades e da criminalização seletiva incide em medida correspondente sobre o estado das relações de poder entre as classes, de modo a oferecer um salvo-conduto mais ou menos amplo para as práticas ilegais de grupos dominantes, no ataque aos interesses e aos direitos das classes subalternas, ou de nações mais fracas; além disso incide, em razão inversamente proporcional à força e ao poder de controle político alcançado pelas classes subalternas, no interior das relações concretas de hegemonia, com uma mais ou menos rigorosa restrição de ações políticas dos movimentos de emancipação social. (BARATTA, 2002, p. 198).

Como Márcia Martini (2007, p. 45-46) informa:

A nossa legislação ordinária e especial é rica em demonstrações de seletividade da norma penal. À guisa de exemplo, tem-se a disparidade entre as penas previstas para os crimes contra o patrimônio público e privado. O crime de roubo é punido muito mais severamente do que o de sonegação fiscal, levando à conclusão de que, para o conjunto a sociedade brasileira, subtrair uma carteira mediante grave ameaça é mais gravoso do que sonegar milhões em impostos, ainda que o roubo de carteira apresente à vítima somente prejuízos materiais, enquanto a sonegação pode ceifar inúmeras vidas, por subtrair recursos que seriam aplicados em políticas públicas. (MARTINI, 2007, p. 45-46).

Analisando as diferenças entre os crimes praticados pela classe economicamente baixa e a classe alta,

observa-se a desigualdade apresentada pelo sistema penal, nesse sentido, Juarez Cirino dos Santos (1981, p. 51-

52) registra que:

Na formação do capitalismo, a criminalidade é reestruturada (a nível de prática criminal, de definição legal e de repressão penal) pela posição de classe do autor: as massas populares (especialmente lumpens), circunscritas à criminalidade patrimonial, são submetidas a tribunais ordinários e a castigos rigorosos; a burguesia, circulando nos espaços da lei (silêncios, omissões e tolerâncias), move-se no mundo protegido da 'ilegalidade dos direitos' (fraudes, evasões fiscais, comércio irregular, etc., na gênese histórica da criminalidade de 'colarinho branco'), com os privilégios de tribunais especiais, multas e transações, que fazem dessa criminalidade um investimento lucrativo. O sistema penal é erigido para 'gerir diferencialmente' a criminalidade (conforme sua origem social), mas sem suprimi-la. A nova 'tecnologia do poder' desloca o direito de punir da vingança do soberano para a 'defesa social' (entendida como 'defesa das condições' materiais e ideológicas da sociedade capitalista), com base na teoria do contrato social: a condição de membro do corpo social implica aceitação das normais sociais, e sua violação, a aceitação da punição. (SANTOS, 
1981, p. 51-52).

Como, por exemplo, não há que se falar em aplicação analógica da extinção de punibilidade prevista nos crimes tributários ao caso de consumação de furto (art. 155 do Código Penal) e os tribunais ratificam a questão:

\begin{abstract}
HABEAS CORPUS - FURTO DE ENERGIA - TRANCAMENTO DE AÇÃO PENAL - INDÍCIOS SUFICIENTES DE AUTORIA E PROVA DA MATERIALIDADE DO DELITO - PRINCÍPIO DA INSIGNIFICÂNCIA - INAPLICABILIDADE PRETENDIDA APLICAÇÃO ANALÓGICA DA EXTINÇÃO DA PUNIBILIDADE PREVISTA NOS CRIMES TRIBUTÁRIOS - SUPOSTO PAGAMENTO DO DÉBITO ANTES DO RECEBIMENTO DA DENÚNCIA - AUSÊNCIA DE APURAÇÃO DO VALOR DA RES FURTIVA - CONSTRANGIMENTO ILEGAL NÃO CONFIGURADO - ORDEM DENEGADA. O trancamento da ação penal, na via estreita do habeas corpus, somente é possível se houver comprovação, de plano, da atipicidade da conduta, da incidência de causa de extinção da punibilidade ou da ausência de indícios de autoria ou de prova sobre a materialidade do delito. A denúncia do caso em apreço, entretanto, apresenta elementos que indicam a existência de indícios da prática do crime pela paciente. A aplicação do princípio da bagatela estimularia a prática dessa espécie de delito, contribuindo para aumentar a incidência do furto de energia. Se o valor da res furtiva ainda não foi mensurado, tanto que não constou na denúncia o quantum em tese de energia que foi desviado,impossível falar em extinção da punibilidade em virtude de suposta quitação do débito antes do recebimento da denúncia, razão pela qual, a conclusão da instrução processual é imprescindível para esclarecer tal fato. (Grifo nosso).

(TJ-MS - HC: 14013299620168120000 MS 1401329-96.2016.8.12.0000, Relator: Des. Luiz Gonzaga Mendes Marques, Data de Julgamento: 07/03/2016, 2a Câmara Criminal, Data de Publicação: 28/03/2016)
\end{abstract}

Pela teoria do etiquetamento, o sistema capitalista e os conflitos sociaiseconômicos desenvolveram sistemas penais que são reconhecidos pela desigualdade, bem como, por políticas criminais parciais, que servem a interesses de classes dominantes. Assim, a possibilidade da extinção de punibilidade pelo pagamento do tributo nos crimes tributários e a impossibilidade de aplicação no crime de furto simples, representa a política parcial adotada pelo ordenamento jurídico.

Em outras palavras, como especificado por Martini, o diferencial e o fator de mensuração da pena são definidos pelo seguinte dualismo: "pobre rouba, rico sonega" (MARTINI, 2007, p. 46).

Pela Criminologia crítica, construiu-se um tratamento diferenciado em relação aos delitos fiscais que, em regra, ocorrem em altos estratos sociais e a atividade punitiva do Estado é concentrada nas classes desabonadas no que diz respeito às questões materiais e econômicas. Trata-se de uma dinâmica exposta por Baratta:

O direito penal tende a privilegiar os interesses das classes dominantes, e a imunizar do processo de criminalização comportamentos socialmente danosos, típicos dos indivíduos a elas pertencentes, e ligados funcionalmente a existência da acumulação capitalista, e tende a dirigir o processo de criminalização, principalmente, para as formas de desvio típicas das classes subalternas [...] as maiores chances de ser selecionado para fazer parte do sistema penal aparecem, de fato, concentradas nos níveis mais baixos da escala social [...] e não só as normas do direito penal se formam e se aplicam seletivamente, refletindo as relações de desigualdades existentes [...]. (BARATTA, 2002, p. 165).

Como Sutherland (1983) defende, há uma perspectiva materialista da punição, pois, as decisões de política criminal determinam os sujeitos taxados de criminosos e os que possuem imunidade às atividades 
punitivas do Estado, ou seja, àqueles que se encontram no topo da pirâmide social e são possuidores de grande concentração de renda. Ainda, o autor salienta:

Por sua vez a administração política tem pouco vigor em parar tal comportamento [...] Isto exige uma oposição clara entre o público e o governo, por um lado, e os empresários que violam a lei, na ordem . Esta oposição clara evidência da falta de organização contra o crime de colarinho branco. (SUTHERLAND, 1983, p. 256-257). ${ }^{7}$

Como, também, dispõe Vera Regina Pereira de Andrade:

Se criminal é o comportamento criminalizado e se a criminalização não é mais do que um aspecto do conflito que se resolve através da instrumentalização do Direito e, portanto, do Estado por parte de quem é politicamente mais forte, os interesses que estão na base da formação e aplicação do direito Penal não são interesses comuns a todos os cidadãos, mas interesses dos grupos que têm o poder de influir sobre os processos de criminalização. (ANDRADE,1997, p. 213).

Outra conclusão importante relata que o sujeito ativo do delito econômico ou fiscal está muito mais próximo daquele que legisla e julga (mesmo núcleo cultural e axiológico), do que o delinquente do delito comum que está mais distante das figuras ou do grupo que estrutura toda a política criminal. Importante salientar que tanto a função legislativa como os órgãos de persecução penal utilizam a dinâmica de seleção criminal. Portanto, considerando todas as instâncias oficiais, como explica Baratta:

Esta direção de pesquisa parte da consideração de que não pode compreender a criminologia se não se estuda a ação do sistema penal, que a define e reage contra ela, começando pelas normas abstratas até a ação das instâncias oficiais (polícia, juízes, instituições penitenciárias que as aplicam), e que, por isso, o status social de delinquente pressupõe, necessariamente, o efeito da atividade das instâncias oficiais de controle social da delinquência, enquanto não adquire esse status aquele que, apesar de ter realizado o mesmo comportamento punível, não é alcançado, todavia, pela ação daquelas instâncias. Portanto, este não é considerado e tratado pela sociedade como 'delinquente'. (BARATTA, 2002, p. 86).

Ressaltando que, a seleção penal que cria o etiquetamento ou rotulamento, ocorre pela criminalização primária (função legislativa), pela secundária (inquérito policial, processo penal e execução da pena) e se estende pela terciária (sociedade em geral).

Para Sutherland (1983), a noção de seleção penal é totalmente perceptível. Os comportamentos, socialmente censurados, passam por processos institucionais que selecionam, de acordo com a classe social e o poder econômico, aqueles que seriam objeto da norma criminalizadora, da persecução penal e da execução penal. Todo aparato da burocracia penal seria, em verdade, uma espécie de filtro que impediria a passagem de indivíduos bem colocados socialmente.

Para a formação de um Direito Penal não seletivo e, consequentemente, a efetivação de garantias constitucionais, como a proteção da Ordem Econômica (art. 170 da CF), Alexandre Walmott Borges dispõe:

\footnotetext{
${ }^{7}$ Tradução livre. As palavras do autor, in verbis: "In turn the political administration has little force in stopping such behavior [...] This calls for a clear-cut opposition between the public and the government, on the one side, and the businessmen who violate the Law, on the order. This clear cut opposition is evidence of the lack of organization against white collar crime". (SUTHERLAND,
} 
Como transformar o modelo de Estado Empresário em bem-sucedido modelo de bemestar? Demonstra-se, portanto, que a direção programática da Constituição deveria apontar para a solução da dimensão dos Direitos Fundamentais sociais, de uma política econômica que garantisse o acesso aos bens de consumo social, que superasse a clivagem social acentuada e o problema da fruição de Direitos sociais e econômicos, enquanto satisfação de necessidades individuais e não apenas do plano organizacional empresarial do Estado. (BORGES, 2003, p. 232).

Desde 1960, a extinção da punibilidade pelo pagamento do tributo esteve, de alguma forma, ligada aos crimes tributários, mas, sempre ganhando espaço e se ampliando. Bem como, a Criminologia crítica avança em seus estudos.

Pelos novos estudos criminológicos, as forças políticas, em todas as fases de criminalização, influenciam de maneira determinante no processo de seleção criminal e no que diz respeito aos crimes tributários é óbvio que, além das necessidades arrecadatórias do Estado, há a necessidade política de se manter a legitimidade do sistema penal, mantendo as classes subordinadas sob controle por uma suposta igualdade, afinal, àqueles que cometem a fraude fiscal sofrem a criminalização primária e a persecução dos agentes penais, mas, dificilmente chegam à execução penal.

\section{CONCLUSÕES E CONSIDERAÇÕES FINAIS}

A pesquisa apresentada visou à construção de um raciocínio crítico em relação à seletividade do Direito Penal, especificamente sobre a possibilidade de extinção de punibilidade pelo pagamento integral do tributo devido, no âmbito do Direito Penal Tributário.

Utilizou-se como fundamentação de análise crítica a teoria do etiquetamento que é a base teórica da Criminologia crítica.

Para tanto, foram necessárias pesquisas doutrinárias, legislativas e jurisprudenciais sobre os crimes tributários e a ciência da Criminologia.

No desenvolver da pesquisa, fez-se uma análise comparativa entre os delitos fiscais e os delitos comuns e verificou-se a diferença de efeitos penais e extrapenais quando os referidos crimes são cometidos no que diz respeito ao instituto da extinção de punibilidade.

Ou seja, a Lei vigente dispõe que pelo pagamento integral do tributo devido a qualquer tempo, extinguese a punibilidade estatal, afastando-se do sujeito ativo do delito fiscal, a persecução penal, a execução criminal e a possibilidade de que o agente chegue ao estabelecimento prisional e, por outro lado, sendo exemplificado pelo delito de furto, ocorrendo devolução da res furtiva à vítima, isto de maneira espontânea e voluntária, não haverá à extinção de punibilidade, apenas, diminuição de pena ou atenuante genérica. Concluindo-se que há uma seleção

1983, p. 256-257). 
penal que escolhe os criminosos e diferencia as consequências geradas pelos pagamentos ou restituições.

Em aspecto geral, concluiu-se que a seleção do sistema penal viola as finalidades da Ordem Econômica, dispostas no art. 170 da Constituição Federal de 1988. Bem como, os Direitos Fundamentais, individuais e coletivos, consagrados pela Carta Maior, em seu art. $5^{\circ}$. Salientando-se que os delitos fiscais causam imensos prejuízos financeiros, desequilibram o país e a sociedade em geral, em muitos casos, consequências mais significativas do que as causadas pelos delitos comuns.

Pelas pesquisas doutrinárias apresentadas, há estratégias que devem ser efetivadas para que a criminalidade não receba penalizações tão desiguais, diferenciações entre os crimes cometidos pela classe menos favorecida e pela classe mais favorecida ou dominante do poder econômico.

A reação social e a própria reação institucional devem se adequar a realidade social e o controle social deve ser regrado pelo fortalecimento dos interesses coletivos, instrumentalizando o sistema penal de forma igualitária em consonância com a atual Constituição democrática.

Ainda, observou-se que a política criminal adotada atualmente, cria as criminalizações primária, secundária e terciária, incentivando a cadeia criminal, ou seja, a reincidência.

Concluiu-se que os temas em discussão, que envolvem a criminalidade no Direito Penal tributário e a extinção punitiva pelo pagamento do tributo representam um fenômeno punitivo complexo da sociedade contemporânea e que, em aspecto geral, são solucionados pela ciência dogmática do Direito Penal de maneira insatisfatória, ocasionando prejuízos sociais, controle social negligente e o distanciamento da paz social, apontando-se para a necessidade de estudos que visem perspectivas criminológicas extra-sistêmicas, criando políticas criminais satisfatórias.

Observou-se que para a criação de políticas criminais que atendam as atuais necessidades sociais é fundamental a união da ciência do Direito Penal com a ciência da Criminologia, em uma ótica crítica, para que os objetivos sociais sejam alcançados.

Em suma, a pesquisa apresentada explorou um tema que merece muita atenção do Estado e da sociedade, ou seja, o processo de criminalização do sistema penal brasileiro.

\section{TRIBUTARY CRIMES UNDER THE OPTICS OF CRITICAL CRIMINOLOGY: EXTINCTION OF PUNISHMENT FOR THE PAYMENT OF THE TRIBUTE AND THE THEORY LABELING APPROACH}

\section{Abstract}

The present study has the scope of analyzing tax crimes from Critical Criminology, regarding the extinction of 
punishment due to the payment of the due tax and the analysis of the labeling approach, which questions the mechanisms of criminal selection of the Current punitive system, analyzing the differentiation of treatments between common and fiscal crimes. The theoretical framework on criminological and tax issues and prevailing jurisprudence were relevant to the development of the study in its methods of doctrinal and jurisprudential research. It was concluded that the selection of the penal system violates the purposes of the Economic Order, set forth in art. 170 of the Federal Constitution of 1988, as well as the Fundamental Rights, individual and collective, consecrated by the Major Charter in its art. 5th. It was observed that for the creation of criminal policies that meet the current social needs, it is fundamental to unite the science of Criminal Law with the science of Criminology, in a critical perspective, so that social objectives can be achieved. In short, the research explored a topic that deserves much attention from the State and from society, that is, the process of criminalization of the Brazilian penal system.

Keywords: Critical Criminology; Criminal Tax Law; Tax offenses; Punitive extinction for payment; Labeling Theory.

\section{BIBLIOGRAFIA E REFERENCIAS}

ALMEIDA, Gregório Assagra de. Direito Material Coletivo: superação da summa divisio Direito público e Direito privado por uma nova summa divisio constitucionalizada. Belo Horizonte: Del Rey, 2008.

ANDRADE, Vera Regina Pereira de. A ilusão de Segurança Jurídica: do controle da violência à violência do controle penal. Porto Alegre: Livraria do Advogado, 1997.

ANDRADE FILHO, Edmar Oliveira. Direito penal tributário: crimes contra a Ordem Tributária e contra a previdência social. 2 ed. São Paulo: Atlas, 1995.

ARGUELLO, Katie. Do Estado social ao Estado penal: invertendo o discurso da ordem. Disponível em: <http://www.cirino.com.br/artigos/Artigo\%20Katie.pdf>. Acesso em: 09 de mar. de 2016.

BARATTA, Alessandro. Criminologia crítica e crítica do direito penal. Trad. Juarez Cirino dos Santos. 2 ed. Rio de Janeiro: Freitas Bastos, 1999.

Criminologia Crítica e crítica do Direito Penal: introdução à sociologia do direito penal.Trad. de Juarez Cirino dos Santos. 3. ed. Rio de Janeiro: Revan - Instituto Carioca de Criminologia, 2002.

Criminologia crítica e crítica do direito penal: introdução à sociologia do direito penal. Trad. de Juarez Cirino dos Santos. 6. Ed. Rio de Janeiro: Revan - Instituto Carioca de Criminologia, 2011.

BARROSO, Daniel Viegas S. Criminologia: Do Estado de Polícia ao Estado de Direito. Florianópolis: Conceito, 2009.

BECCARIA, Cesare. Dos delitos e das penas. Trad. Flórido De Angelis. Bauru: Edipro, 2001.

BORGES, Alexandre Walmott. Preâmbulo da Constituição \& a Ordem Econômica. Curitiba: Juruá, 2003.

BRASIL. Constituição Da República Federativa Do Brasil De 1988. Disponível em: <http://www.planalto.gov.br/ccivil_03/Constituicao/Constitui\%C3\%A7ao.htm>. Acesso em 24 mar de 2016.

Decreto-Lei n. 2.848, de 07 de dezembro de 1940. Código Penal. Disponível em: <http://www.planalto.gov.br/ccivil_03/decreto-lei/Del2848.htm>. Acesso em 03 de abr. de 2016. 
Decreto-lei n. 3.689, de 3 de outubro de 1941. Código de Processo Penal. Disponível em: <http://www.planalto.gov.br/ccivil_03/decreto-lei/del3689compilado.htm>. Acesso em 03 de abr. de 2016.

Lei n. 4.729, de 14 de julho de 1965. Define o crime de sonegação fiscal e dá outras providências. Disponível em: <http://www.planalto.gov.br/ccivil_03/leis/1950-1969/L4729.htm>. Acesso em 03 de abr. de 2016.

Lei n. 8.137, de 27 de dezembro de 1990. Define crimes contra a Ordem Tributária, econômica e contra as relações de consumo, e dá outras providências. Disponível em: <http://www.planalto.gov.br/ccivil_03/leis/L8137.htm>. Acesso em 03 de abr. de 2016.

Lei n. 10.684, de 30 de maio de 2003. Define crimes contra a Ordem Tributária, econômica e contra as relações de consumo, e dá outras providências. Disponível em: <http://www.planalto.gov.br/ccivil_03/leis/2003/L10.684.htm>. Acesso em 03 de abr. de 2016.

Lei no 12.382, de 25 de fevereiro de 2011. Define crimes contra a Ordem Tributária, econômica e contra as relações de consumo, e dá outras providências. Disponível em: <http://www.planalto.gov.br/ccivil_03/_Ato2011-2014/2011/Lei/L12382.htm>. Acesso em 03 de abr. de 2016.

Supremo Tribunal Federal. Embargos de declaração na ação penal n. 516, Distrito Federal. Relator Min. Ayres Britto. Data da decisão: 05/12/2013. Disponível em: http://stf.jusbrasil.com.br/jurisprudencia/25342620/embdecl-na-acao-penal-ap-516-df-stf. Acesso em: 06 de jul. de 2016.

Supremo Tribunal Federal. Questão de ordem na ação penal n. 613, Tocantins. Relator Min. Carmén Lúcia. Data da decisão: 15/05/2014. Disponível em: http://stf.jusbrasil.com.br/jurisprudencia/25110754/questao-de-ordem-na-acao-penal-ap-613-to-stf. Acesso em: 06 de jul. de 2016.

Superior Tribunal de Justiça. RHC: 12383 SP 2002/0008050-2, Relator: Ministro GILSON DIPP, Data de Julgamento: 19/02/2004, T5 - QUINTA TURMA, Data de Publicação: <!-- DTPB: 20040405<br> --> DJ 05/04/2004 p. 275. Disponível em: <http://stj.jusbrasil.com.br/jurisprudencia/7380887/recurso-ordinario-emhabeas-corpus-rhc-12383-sp-2002-0008050-2>. Acesso em: 06 de jul. de 2016.

Superior Tribunal de Justiça. AgRg no AREsp: 401904 SP 2013/0327374-4, Relator: Ministro MOURA RIBEIRO, Data de Julgamento: 06/02/2014, T5 - QUINTA TURMA, Data de Publicação: DJe 12/02/2014). Disponível em: <http://stj.jusbrasil.com.br/jurisprudencia/24901121/agravo-regimental-no-agravo-emrecurso-especial-agrg-no-aresp-401904-sp-2013-0327374-4-stj>. Acesso em: 06 de jul. de 2016.

Superior Tribunal de Justiça. RHC: 56665 PE 2015/0033022-0, Relator: Ministra MARIA THEREZA DE ASSIS MOURA, Data de Julgamento: 19/03/2015, T6 - SEXTA TURMA, Data de Publicação: DJe 27/03/2015). Disponível em: <http://sti.jusbrasil.com.br/jurisprudencia/178705589/recurso-ordinario-emhabeas-corpus-rhc-56665-pe-2015-0033022-0. Acesso em: 06 de jul. de 2016.

Tribunal Regional Federal. TRF-1 - HC: 4298 GO 0004298-84.2011.4.01.0000, Relator: JUIZ TOURINHO NETO, Data de Julgamento: 14/03/2011, TERCEIRA TURMA, Data de Publicação: e-DJF1 p.178 de 31/03/2011). Disponível em: <http://trf-1.jusbrasil.com.br/jurisprudencia/18700624/habeas-corpushc-4298-go-0004298-8420114010000>. Acesso em: 06 de jul. de 2016.

Tribunal Regional Federal. TRF-3 - HC: 00284795620154030000 SP 0028479-56.2015.4.03.0000, Relator: DESEMBARGADOR FEDERAL JOSÉ LUNARDELLI, Data de Julgamento: 02/02/2016, DÉCIMA PRIMEIRA TURMA, Data de Publicação: e-DJF3 Judicial 1 DATA:12/02/2016. Disponível em: <http://trf3.jusbrasil.com.br/jurisprudencia/317147601/habeas-corpus-hc-284795620154030000-sp-0028479-

5620154030000. Acesso em: 06 de jul. de 2016.

Tribunal de Justiça. TJ-PR - RVCR: 14263268 PR 1426326-8 (Acórdão), Relator: Telmo Cherem, Data de Julgamento: 11/02/2016, $1^{\text {a }}$ Câmara Criminal em Composição Integral, Data de Publicação: DJ: 1745 23/02/2016). Disponível em: <http://tj-pr.jusbrasil.com.br/jurisprudencia/307973513/revisao-criminal-rvcr14263268-pr-1426326-8-acordao. Acesso em: 06 de jul. de 2016. 
CAPEZ, Fernando. Curso de Direito Penal: legislação penal especial. Volume 4. 7. ed. São Paulo: Saraiva, 2012.

CAVALCANTE, Márcio André Lopes. Principais julgados do STF e STJ comentados 2013. Manaus: Dizer o direito, 2014.

CERVINI, Raúl. Derecho penal econômico. Concepto y bien jurídico. Revista do IBCCRIM, São Paulo, ano 11, n. 43, p. 96-108, 2003.

CORRÊA, Antonio. Dos crimes contra a Ordem Tributária. São Paulo: Afiliada, 1994

COSTA, Elder Lisboa Ferreira da. Os delitos econômicos na atualidade. In: D’AVILA, Fábio Roberto; SPORLEDER, Paulo Vinícius. Direito penal secundário. São Paulo: Revista dos Tribunais, 2006.

DIAS, Jorge de Figueiredo. Para uma dogmática do direito penal secundário. In: D’AVILA, Fábio Roberto; SPORLEDER, Paulo Vinícius. Direito penal secundário. São Paulo: Revista dos Tribunais, 2006.

DIAS, Jorge de Figueiredo; ANDRADE, Manuel Costa. Criminologia: o homem delinqüente e a sociedade criminógena. Coimbra: Coimbra Editora, 1997.

FERNANDES, Newton. FERNANDES, Valter. Criminologia Integrada. 2. ed. São Paulo: Revista dos Tribunais, 2002.

GARLAND, David. Punishment and modern society: a study in social theory. Chicago: The University of Chicago Press, 1990.

HASSEMER, Winfried. Introdução à criminologia. Trad. de Cíntia Toledo Miranda Chaves. Rio de Janeiro: Lúmen Juris, 2000.

ISHIDA, Válter Kenji. Processo Penal. 2. ed. São Paulo: Atlas, 2010.

LEMOS JÚNIOR, Artur Pinto de. O direito penal secundário e a ampliação do conceito de autor. In: D’AVILA, Fábio Roberto; SPORLEDER, Paulo Vinícius. Direito penal secundário. São Paulo: Revista dos Tribunais, 2006.

LIMA PINTO, Emerson de. A criminalidade econômico - tributaria. A (des) ordem da lei e a lei da (des) ordem. Porto Alegre: Livraria do Advogado, 2001.

MACHADO, Hugo de Britto. Crimes contra a Ordem Tributária. 3. ed. São Paulo: Atlas, 2011.

MARTINI, Márcia. A seletividade punitiva como instrumento de controle das classes perigosas. MPMG. Jurídico. Ano III, $\quad \mathrm{n}^{\circ} \quad 11.2007 .2$ Disponível em: <https://aplicacao.mpmg.mp.br/xmlui/bitstream/handle/123456789/650/3.4.1\%20A\%20seletividade\%20pun itiva.pdf?sequence $=1>$. Acesso em: 02 de jul. de 2016 .

MARX, Karl. O Capital Trad. Regis Barbosa e Flávio R. Kothe. São Paulo: Abril cultural, 2002.

MOLINA, Antônio Garcia-Pablos de; GOMES, Luiz Flávio. Criminologia. 3 ed. rev. atual. e amp. São Paulo: Revista dos Tribunais, 2000. 
MOLINA, Antônio Garcia-Pablos de. GOMES, Luiz Flávio. Criminologia. 4. ed. São Paulo: Revista dos Tribunais, 2002.

NUCCI, Guilherme de Souza. Manual de direito penal: parte geral: parte especial. 6 ed. rev. atual. E ampl. São Paulo: Revista dos Tribunais, 2009.

OLIVEIRA E SILVA, Eduardo Sanz de. O princípio da Subsidiariedade e a Expansão do Direito Penal Econômico. In: D’AVILA, Fábio Roberto; SPORLEDER, Paulo Vinícius. Direito penal secundário. São Paulo: Revista dos Tribunais, 2006.

PENTEADO FILHO, Nestor Sampaio. Manual Esquemático de Criminologia. 3. ed. São Paulo: Saraiva. 2013.

PIMENTEL, Manoel Pedro. Direito Penal Econômico. RT. São Paulo. 1973.

O Crime e a Pena na Atualidade. São Paulo: Revista dos Tribunais, 1983.

REGIS PRADO, Luiz. Direito penal econômico. São Paulo: Revista dos Tribunais, 2004.

SANTOS, Juarez Cirino dos. A criminologia radical Rio de Janeiro: Forense, 1981.

SCHMMIDT, Andrei. A exclusão da punibilidade em crimes de sonegação fiscal. Rio de Janeiro: Lumen Juris, 2003.

SHIRAKI, Ariella Toyama. A legitimidade do direito penal econômico como direito penal de perigo - Uma análise à luz dos princípios da lesividade e da intervenção mínima. Revista do IBCCRIM, São Paulo, ano 18, n. 83, p. 8-51,2010.

SILVA, José Afonso. Curso de Direito Constitucional Positivo. 18. ed. São Paulo: Malheiros, 2000.

SOUSA, Susana Aires de. Os crimes fiscais. Análise dogmática e reflexão sobre a legitimidade do discurso criminalizador. Coimbra: Coimbra, 2006.

SMITH, Adam. A Riqueza das Nações. Trad. Luiz João Baraúna, São Paulo: Abril Cultural, 1983.

SUTHERLAND, Edwin. White collar crime. Part I. Yale University, 1983.

ZAFFARONI, Eugênio Raúl; PIERANGELI, José Henrique. Manual de direito penal brasileiro. 2 ed. rev. e atual. São Paulo: Revista dos Tribunais, 1999.

Trabalho enviado em 05 de agosto de 2017.

Aceito em 09 de novembro de 2017. 